\title{
How a typical West African day in the future-climate compares with current-climate conditions in a convection-permitting and parameterised convection climate model
}

\author{
Rory G. J. Fitzpatrick ${ }^{1}$ (D) Douglas J. Parker ${ }^{1} \cdot$ John H. Marsham $^{1} \cdot$ David P. Rowell $^{2}$. \\ Lawrence S. Jackson ${ }^{1} \cdot$ Declan Finney $^{1} \cdot$ Chetan Deva $^{1} \cdot$ Simon Tucker $^{2}$. \\ Rachael Stratton ${ }^{2}$
}

Received: 23 April 2019 / Accepted: 25 September 2020 /Published online: 22 October 2020

(C) The Author(s) 2020

\begin{abstract}
Current-climate precipitation and temperature extremes have been identified by decision makers in West Africa as among the more impactful weather events causing lasting socioeconomic damage. In this article, we use a plausible future-climate scenario (RCP8.5) for the end of the twenty-first century to explore the relative commonness of such extremes under global warming. The analysis presented considers what a typical day in the future climate will feel like relative to current extrema. Across much of West Africa, we see that the typical future-climate day has maximum and minimum temperatures greater than $99.5 \%$ of currently experienced values. This finding exists for most months but is particularly pronounced during the Boreal spring and summer. The typical future precipitation event has a daily rainfall rate greater than $95 \%$ of current storms. These findings exist in both a future scenario model run with and without parameterised convection, and for many of the Coupled Model Inter-comparison Project version 5 ensemble members. Additionally, agronomic monsoon onset is projected to occur later and have greater inter-annual variability in the future. Our findings suggest far more extreme conditions in future climate over West Africa. The projected changes in temperature and precipitation could have serious socioeconomic implications, stressing the need for effective mitigation given the potential lack of adaptation pathways available to decision makers.
\end{abstract}

Keywords Climate change $\cdot$ Africa $\cdot$ Impacts $\cdot$ Convection-permitting $\cdot$ Precipitation $\cdot$ Sahel

Rory G. J. Fitzpatrick

R.G.J.Fitzpatrick@leeds.ac.uk

1 Institute of Climate and Atmospheric Sciences, University of Leeds, Leeds, UK

2 Met Office, Exeter, UK 


\section{Introduction}

The Inter-governmental Panel for Climate Change (IPCC) 5th assessment report (AR5) highlights the risks associated with a business-as-usual approach towards climate change. This approach is projected to lead to a $3-6{ }^{\circ} \mathrm{C}$ warming across the globe by the end of the twenty-first century. Such a rise is predicted, with high confidence, to lead to increased food insecurity and heightened health risks over West Africa. The risks of climate change are often felt disproportionately strongly by the most vulnerable communities, who also have less available pathways for adaptation to, and mitigation of, climate change (IPCC AR5). Many weather related socioeconomic risks are associated with extremes of temperature or precipitation (Visman et al. 2017; Barry et al. 2018), although other metrics such as wind gusts and humidity can also pose challenges.

There is a continued need for improved climate change projections and interpretation of their potential socioeconomic impacts. Further, the nature of how climate change information is presented is of interest as public engagement is vital to addressing future issues associated with climate change. The recent development of the convection-permitting resolution Future Climate for Africa (FCFA) Improving Model Processes for African Climate (IMPALA) simulations for the entire African continent allows for in-depth investigation of the added value of simulations without convection-parameterisation schemes over the region and potentially more feasible projections of climate change over the continent.

In this paper, we evaluate the relative intensity of the future climate over West Africa, with regard to select decision-maker-relevant metrics, and contextualise these changes with respect to socioeconomic challenges. In order to reach this goal, we employ a novel approach to assess the relative intensity of rainfall and temperature values for a typical future-climate day relative to present conditions in FCFA simulations produced with and without an active convection parameterisation scheme. The metrics chosen have previously been co-constructed with decision makers in West Africa through the African Monsoon Multidisciplinary Analysis for 2050 project (Visman et al. 2017). Using current literature as a guide, the potential impacts of our results on agricultural and livestock practices as well as their impacts on human health are subsequently considered at length.

Section 2 provides the background motivation for our work. Section 3 describes data used henceforth, whilst Sect. 4 presents the methods employed. Section 5 provides projected changes in selected temperature and rainfall-related metrics. A discussion of potential socioeconomic impacts of our results is given in Sect. 6 with conclusions presented in Sect. 7.

\section{Background}

\subsection{Current and projected future trends of rainfall and temperature changes over West Africa}

Countries across West Africa are particularly vulnerable to global warming and its subsequent effects, both due to their exposure to extreme weather events and relatively low adaptive capacity compared with other regions of the globe (Dai et al. 2004; IPCC AR5; Niang et al. 2014). These nations have frequently contended with high-impact weather (HIW) events, such as: flooding events (Tarhule 2005; Di Baldassarre et al. 2010; Nka et al. 2015; Casse et al. 2016; Tazen et al. 2018), prolonged dry spells (Giraldo Osorio and Garcia Galiano 2012; 
Rodriguez-Fonseca et al. 2015), and heatwaves (New et al. 2006; Fontaine et al. 2013; Ly et al. 2013; Moron et al. 2016; Ceccherini et al. 2017). A recent trend towards warmer night-time temperatures and hotter days is also found by Barry et al. (2018).

Although the magnitude of climate change over West Africa differs between projections, not least because future emissions are uncertain, there is a broad consensus towards more extreme weather conditions over the region in the future. Under the Inter-governmental Panel on Climate Change regional climate pathway 8.5 (RCP8.5), near-surface temperatures in many regions of the world could exceed any currently experienced values within the next 30 years (Mora et al. 2013), with absolute increases in annual minimum temperatures projected to exceed those of maximum temperatures (Vizy and Cook 2012; Bamba et al. 2017). Global and regionally downscaled climate models project near-surface temperatures to increase by around 3- $6{ }^{\circ} \mathrm{C}$ by the end of the twenty-first century (Patricola and Cook 2010; Fontaine et al. 2011; Mariotti et al. 2011; Diallo et al. 2012; Vizy et al. 2013; Riede et al. 2016). Further, extreme hot days (>90th percentile of present climate) are expected to be more frequent (Russo et al. 2014; Dosio 2017; Weber et al. 2018; Nangombe et al. 2019; Yapo et al. 2019).

Precipitation projections often exhibit a west-east dipole in relative precipitation changes, with more rain than present projected over the Eastern Sahel and less rainfall projected over the Western Sahel (Biasutti 2013; James et al. 2014; Diallo et al. 2016; Nikulin et al. 2018). However, some projections show a more zonally homogeneous increase (Vizy et al. 2013). Fewer rainfall events and a reduction in consecutive wet days are projected for much of West Africa (Klutse et al. 2018). Despite the reduction in events, an increase in 5-day precipitation maximum is simulated near the Guinea Coast and Nigeria by the end of the twenty-first century (Diallo et al. 2016; Nikulin et al. 2018). Projections therefore point towards a climate with less frequent, more intermittent, but more intense rainfall events over much of West Africa, which is also seen in convection-permitting simulations (Fitzpatrick et al. 2020). Further, there is a potential change in the seasonality of the Sahelian rainy season, with a later onset and the potential for a mid-season break period by the end of the twenty-first century (Riede et al. 2016; Dunning et al. 2018).

\subsection{Modelled representation of convection over West Africa}

Model simulations with horizontal grid spacing greater than approximately $10 \mathrm{~km}$ require parameterisation schemes in order to resolve convection (Pennelly et al. 2014); these systems act to determine the collective effect of multiple clouds within a grid box rather than resolving the effect of singular clouds on the vertical profile (Arakawa and Schubert 1974).

Due to computational expense, the majority of future-climate projections available for West Africa are produced at grid spacing requiring convection parameterisation schemes. Simulations with convection parameterisation schemes can struggle to model Sahelian storms and their intensities accurately (Marsham et al. 2013; Crook et al. 2019). Convection-permitting models have been shown to realistically simulate present-day monsoon flow (Marsham et al. 2013; Stratton et al. 2018), convergence (Birch et al. 2014a, 2014b), the diurnal cycle of rainfall (Vizy and Cook 2018a, 2018b), and the characteristics of intense precipitation events (Berthou et al. 2019). Convection parameterisation schemes can also have temperature biases over the region due to their poor representation of cold pools, or overabundance of cloud (Garcia-Carreras et al. 2013; Berthou et al. 2019), and can affect crop yield simulations (Garcia-Carreras et al. 2015).

The Met Office Unified Model Convection Permitting for Africa (CP4-A) simulations, produced as part of the FCFA IMPALA project provide 10 years of present and future- 
climate simulations for the entire African continent at convection-permitting spatial resolution (Stratton et al. 2018; Kendon et al. 2019). The accessibility of this new simulation provides the opportunity to consider projected changes in weather conditions between the current and future climate within models which can better represent temperature and rainfall over West Africa.

\subsection{Presentation of climate information}

Alongside technological improvements, such as the availability of convection-permitting simulations for West Africa, there is a need to consider methodological decision which can improve the value of climate information for decision makers (Murphy 1993). Fitzpatrick et al. (2016) consider climate information value to involve not only the quality of findings but also their relevance, necessity for decision makers, and their availability. Co-production projects can help improve the relevance of climate information for stakeholders by directly involving a wide swath of individuals and their concerns in the identification and selection of climate change metrics considered (Visman et al. 2017; Barry et al. 2018). This approach is of use for improving the value of subsequent climate studies.

Recent studies have contextualised future conditions in major urban regions across the globe relative to present-day conditions elsewhere on the planet (Fitzpatrick and Dunn 2019; Bastin et al. 2019). However, in a meta-study of climate engagement articles, Nicolosi and Corbett (2018) highlight that stakeholder engagement with climate change information is significantly increased when place influence engagement is considered (i.e. changes at their locale exclusively are considered). In this article, we expand on the current literature by considering the findings of Mora et al. (2013) and Nicolosi and Corbett (2018), by describing what a futureclimate "typical" day may feel like relative to present-day variability at set locations.

Contextualising future-climate metrics in terms of current-day values allows for decision makers to relate projected values to personal experiences. The approach embraces a "seamless" approach to weather and climate prediction, acknowledging that the effects of climate change many years hence will be experienced by people on timescales of days, and therefore should be interpreted on such timescales. Our method was further inspired by a poster presented at the American Meteorological Society 99th Annual Meeting by Jacob C. Muller from the University of Oklahoma (https://ams.confex.com/ams/98Annual/webprogram/Paper338333.html) where a similar idea was used to contextualise present-day temperatures relative to historical values on a daily timescale. The author does not know of any peer-reviewed publication detailing the methodology of Muller et al. but wish to acknowledge them.

\section{Data}

The limited area FCFA simulations produced by the Met Office are used in this study. These simulations span the entire African continent and are available for both a representative presentday climate (1997-2006) and for a feasible end-of-century projection following the RCP8.5 (Stratton et al. 2018; Kendon et al. 2019). Model output has been produced at $\sim 25 \mathrm{~km}$ horizontal resolution with an active convection parameterisation scheme (henceforth referred to as the parameterised simulations of P25), and at $\sim 4.4 \mathrm{~km}$ grid spacing with no active convection parameterisation scheme (termed $\mathrm{CP} 4-\mathrm{A}$, or the convection-permitting simulations).

CP4-A and P25 are regional models with longitudinal boundaries at $24^{\circ} \mathrm{W}$ and $56^{\circ} \mathrm{E}$ and latitudinal boundaries at $45^{\circ} \mathrm{S}$ and $39^{\circ} \mathrm{N}$. The models are forced using lateral boundary 
conditions from an atmosphere-only version the UK Met Office Global Climate Model (GCM) with $25 \mathrm{~km}$ horizontal grid spacing. CP4-A uses an applied moisture conservation scheme (Aranami et al. 2015) and a three-dimensional blended boundary layer scheme (Boutle et al. 2014). The large-scale cloud scheme is described in Smith (1990) and has been used in other convection-permitting versions of the Met Office Unified Model. Ice water content is determined by the microphysics scheme, with cloud fractions then diagnosed as in Abel et al. (2017). Other parameterisation schemes are documented in Table 2 of Stratton et al. (2018).

In each climate, the same sea-surface temperatures (SSTs) are given to the driving GCM, P25, and CP4-A. Present-day simulations use prescribed daily sea surface temperatures from the Reynolds observational dataset (Reynolds et al. 2007). For the future-climate simulations, SSTs are given by quantifying the climatological change in SST values simulated between 1975 and 2005 and 2085 and 2115 from a GCM run using the Coupled Model RCP8.5. This climatological SST change was calculated monthly, interpolated both spatially and temporally, and added to the current-climate values taken from Reynolds et al. (2007) to produce future SSTs. Finally, greenhouse gas increases are taken from the RCP8.5 scenario for 2100. Future changes in precipitation rates across West Africa between the two simulations are attributable solely to rising temperatures and increases in greenhouse gases.

Producing continental-scale, convection-permitting climate data over two 10-year time spans incurs an extensive computational expense. As such, there has been a need to compromise during the production of the $\mathrm{CP} 4-\mathrm{A}$ dataset, and there exists only one model representation for the current and future climates respectively. We stress that the CP4-A and P25 results presented in this paper provide communicative results based on a single, plausible future climate.

For comparison, Section 5.1 frames maximum temperature changes seen in CP4-A and P25 in the context of an end-of-century bias-corrected version of the Coupled Model Inter-comparison Project version 5 (CMIP5) following RCP8.5 produced by Famien et al. (2018). This dataset was produced for the domain $20^{\circ} \mathrm{W}-55^{\circ} \mathrm{E}, 40^{\circ} \mathrm{S}-$ $40^{\circ} \mathrm{N}$ and for the time period 1950-2099. Data are normalised to a regular $0.5 \times 0.5^{\circ}$ grid. Temperature, wind, and radiation data are bias corrected using the cumulative distribution function transform method documented in Michelangeli et al. (2009), whereas precipitation rates are bias corrected using a singularity stochastic removal approach (Vrac et al. 2016) which considers the temporal intermittency of rainfall events. All variables are bias corrected against the WFDEI meteorological forcing dataset (Weedon et al. 2014) and calibrated for the initial period 1979-2013. The bias corrected dataset more closely matches reanalysis data compared with the raw CMIP5 output, including reducing the cold bias over the Sahel present in many CMIP5 models. The 29 bias-corrected simulations available are listed in Table 1 of Famien et al. (2018). The analysis presented in Section 5.1 has been produced for all months, with similar conclusions drawn. Due to the relatively coarse grid spacing in the CMIP5 ensemble members analysed, we have not done similar analysis for the relative intensification of precipitation events.

\section{Methods}

Through discussions with African decision makers (including representatives of farmers, vets, city planners, and members of the media), alongside agricultural and hydrological researchers, a glossary of key stakeholder-relevant HIW metrics has been produced (Visman et al. 2017). 
Table 1 List of high impact weather (HIW) metrics agreed with West African stakeholder used within this paper

\begin{tabular}{|c|c|c|}
\hline Metric name & $\begin{array}{l}\text { Timeframe } \\
\text { assessed over }\end{array}$ & Definition \\
\hline $\begin{array}{l}\text { Maximum near-surface } \\
\text { temperature }\end{array}$ & Daily & $\begin{array}{l}\text { The maximum 1-h daily } 1.5 \mathrm{~m} \text { temperature observed at each } \\
\text { grid cell on any given day. }\end{array}$ \\
\hline $\begin{array}{l}\text { Minimum near-surface } \\
\text { temperature }\end{array}$ & Daily & $\begin{array}{l}\text { The minimum 1-h daily } 1.5 \mathrm{~m} \text { temperature observed at each } \\
\text { grid cell on any given day. }\end{array}$ \\
\hline Daily rainfall intensity & Daily & $\begin{array}{l}\text { The daily precipitation rate at a location for days when the } \\
\text { maximum precipitation rate exceeds } 1 \mathrm{~mm} / \mathrm{h} \text {. At least } 10 \\
\text { such rain events must occur at a given location each year } \\
\text { for this value to be recorded. }\end{array}$ \\
\hline Local onset date & Seasonal & $\begin{array}{l}\text { Taken from Marteau et al. (2009). Local onset at a given } \\
\text { location is calculated as the first rainy day (precipitation } \\
>1 \mathrm{~mm} \text { ) of } 2 \text { consecutive rainy days (total precipitation } \\
>20 \mathrm{~mm} \text { ) with no } 7 \text {-day period of total precipitation } \\
<5 \mathrm{~mm} \text { in the subsequent } 20 \text { days. }\end{array}$ \\
\hline False onset rate & Seasonal & $\begin{array}{l}\text { Taken as the number of times a rain event (of at least } 20 \mathrm{~mm} \text { ) } \\
\text { occurs prior to local onset date. }\end{array}$ \\
\hline
\end{tabular}

The HIW glossary has previously been used to create climate atlases for different sub-domains of the African continent which are publically available (https://www.amma2050. org/content/climate-atlas; Bamba et al. 2017).

Here, we use a selected subset of these metrics relating to changes in temperature and precipitation extremes (Table 1). We stress that the set of metrics evaluated here are not intended to represent a comprehensive list of all decision-relevant climate metrics identified by stakeholders associated with AMMA-2050 nor those investigated in other works (e.g. Mora et al. 2017; Sylla et al. 2018). Rather, this work aims to present a novel method of visualising climate change using a specific set of high-impact-weather indicators.

For each HIW metrics, we compute the median value simulated by P25 and CP4-A for each location across the current and future climate; this measurement represents our "typical" day/ event in each climate for the respective metric. We then compare difference in the median metrics to provide insight into the absolute change in temperature and precipitation metrics across climates. We further calculate where the median future-climate value for each metric sits on the modelled range of current climate. This measurement gives a relative intensity of future typical conditions relative to the historical perspective. For example, if the median future-climate maximum temperature value at a given location lies beyond the 90 th percentile of current-climate values, we state that a typical future-climate day is hotter than $90 \%$ of simulated current-climate days.

Weather metrics are either assessed daily (e.g. maximum daily temperature), or seasonally (e.g. local onset date) depending on the most relevant time frame. For daily temperature metrics, we assess future changes on a month-by-month basis to remove seasonal variability. Two specific months are highlighted hereafter, namely May and August. August represents the peak monsoon month across the Sahel (10-18 N: Sultan and Janicot 2000, 2003; Thorncroft et al. 2011; Lafore et al. 2011), whilst May marks the beginning of the agronomic onset period, for the same region (Marteau et al. 2009, 2011; Fitzpatrick et al. 2015), and is a period of nearpeak temperatures in the Sahel. Precipitation metrics are computed annually due to the identified reduction in rain events within CP4-A and P25 under global warming (Kendon et al. 2019; Fitzpatrick et al. 2020). 
The local monsoon onset definition used in this article, from Marteau et al. (2009), has previously been preferred over other local definitions due to its direct relevance for agronomic decision makers. As local monsoon onset and withdrawal occur once a year, these values are calculated annually, similar to Marteau et al. (2009), Fitzpatrick et al. (2015), and Riede et al. (2016). False onsets are calculated when an initial precipitation event is not succeeded by persistent rainfall as defined in Marteau et al. (2009) and Fitzpatrick et al. (2015).

For temperature and precipitation metrics, model output is compared over the region $20^{\circ}$ $\mathrm{W}-20^{\circ} \mathrm{E}, 0-30^{\circ} \mathrm{N}$ (Fig. 1). For agronomic onset metrics, model output is evaluated across the Sahel $\left(15^{\circ} \mathrm{W}-15^{\circ} \mathrm{E}, 10-18^{\circ} \mathrm{N}\right)$. Figure 1 additionally highlights approximate geographical bounds of the Guinea Coast and the Sahara, which we refer to occasionally in Sect. 5.

\section{Results}

\subsection{Changes in daily temperature values}

Figure 2 shows the change in maximum near-surface temperature during May in the current and future climates for both CP4-A and P25. Current-climate median daily maximum temperatures simulated during May within P25 are 1-2 ${ }^{\circ} \mathrm{C}$ greater than those seen in CP4-A over southern Mauritania, Mali and south-western Niger (Fig. 2a, b). Overall, there is good agreement in the spatial distribution and magnitude of values between the two models, with the above-stated exception. Towards the Guinea Coast and farther east near Chad, the models show closer agreement in the median daily maximum temperatures during this month. Values over the Guinea Coast range from 26 to $35^{\circ} \mathrm{C}$ in both models, with zonal minima found over Guinea and Cameroon. Over the Sahel, temperatures range from about $38-44{ }^{\circ} \mathrm{C}$; these typical daily maximum temperatures align with the expectation of a meridional temperature gradient

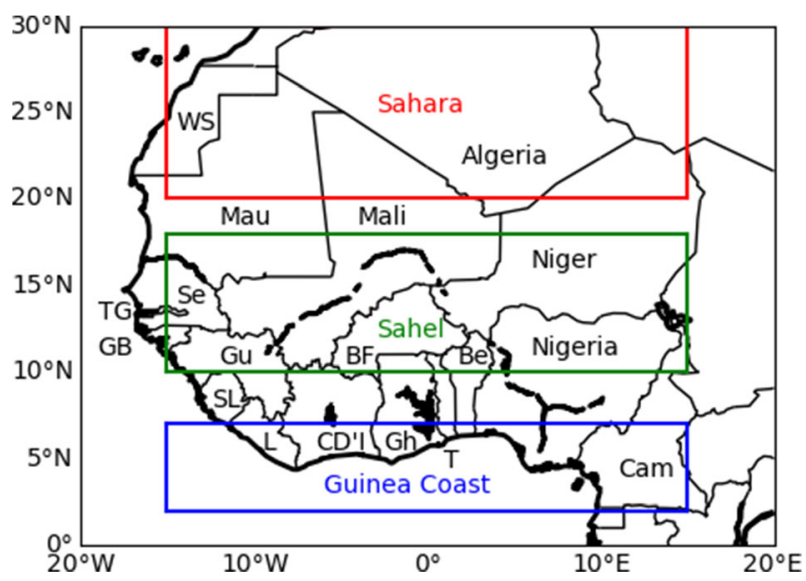

Fig. 1 Study region for comparison of decision maker-relevant metrics across climates. Blue box denotes the Guinea Coast region $\left(15^{\circ} \mathrm{W}-15^{\circ} \mathrm{E}, 2-7^{\circ} \mathrm{N}\right)$, whilst the green and red boxes highlight the Sahel $\left(15^{\circ} \mathrm{W}-15^{\circ} \mathrm{E}\right.$, $\left.10-18^{\circ} \mathrm{N}\right)$ and Sahara $\left(15^{\circ} \mathrm{W}-15^{\circ} \mathrm{E}, 20-30^{\circ} \mathrm{N}\right)$ regions discussed in the analysis. Country abbreviations (black text) from north to south are as follows: WS, Western Sahel; Mau, Mauritania; TG, The Gambia; Se, Senegal; GB, Guinea-Bissau; Gu, Guinea; BF, Burkina Faso; Be, Benin; SL, Sierra Leone; L, Liberia; CD’I, Côte D'Ivoire (Ivory Coast); Gh, Ghana; T, Togo; Cam, Cameroon 


\section{May comparison}

(a)

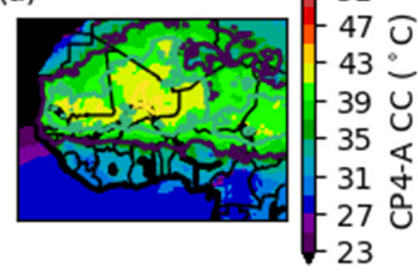

(c)

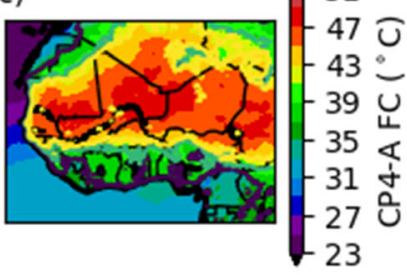

(e)

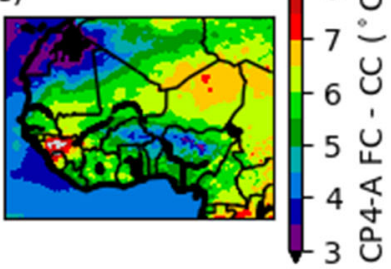

(b)

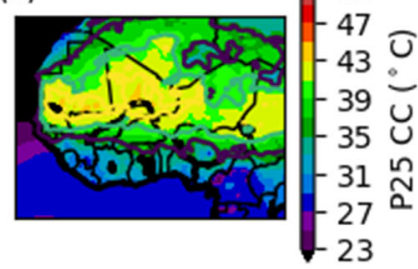

(d)

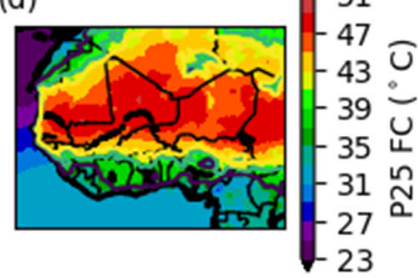

(f)

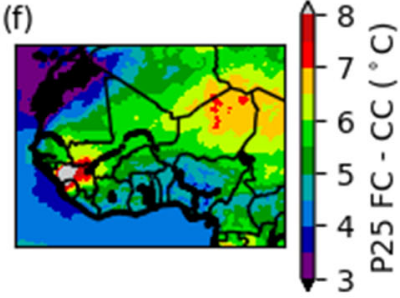

(g)
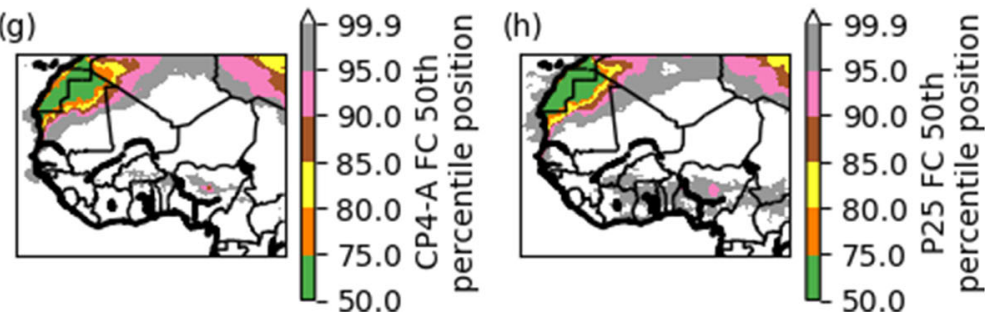

Fig. 2 Comparison of typical daily maximum temperatures during May in the current- and future-climate simulations of CP4-A and P25. a, b The typical (median) daily maximum temperature at $1.5 \mathrm{~m}$ above the surface during May from the CP4-A and P25 current-climate output, respectively, with (c) and (d) showing the same metric for the future-climate model runs. e, f The absolute difference between future- and current-climate typical values for each model. $\mathbf{g}, \mathbf{h}$ The percentile of the simulated current-climate distribution from each model which corresponds to the typical (median) future-climate daily maximum near-surface temperature. White regions in (g) and (h) denote locations where the future typical daily maximum temperature is warmer than $99.9 \%$ of current-climate values

across West Africa. It is also of note that May represents the approximate end of the coastal rainfall phase across West Africa, but predates the seasonal installation of the Sahelian rain belt (Thorncroft et al. 2011). The meridional contrast seen in Fig. 2a, b is consistent with observations (c.f. Evan et al. 2015). 
In the future climate, the meridional difference in median daily maximum temperatures during May is still evident in both models (Fig. 2c, d). However, the absolute increase in temperature values across Sahelian countries is greater than that found over the Guinea Coast. Specifically, on a typical simulated future-climate May day, maximum daily temperature approach or exceed $50{ }^{\circ} \mathrm{C}$ over parts of northern Senegal, southern Mauritania, Mali, Niger, and western Chad in both simulations. These increases represent a rise of greater than $5.5^{\circ} \mathrm{C}$ in both simulations for Mali and Niger specifically, with similar striking increases apparent over Guinea and Sierra Leone (Fig. 2e, f). By comparison, both models project much smaller increases in typical May maximum daily temperatures over northern Mauritania and the Western Sahara $\left(2-3{ }^{\circ} \mathrm{C}\right)$, and over parts of Burkina Faso, Benin, and northern Nigeria (3$4{ }^{\circ} \mathrm{C}$ ). Over Ghana, southern Nigeria, and northern Cameroon, CP4-A projects higher absolute increases in typical May maximum temperatures (around $5.5^{\circ} \mathrm{C}$ ) than $\mathrm{P} 25$ (about $4{ }^{\circ} \mathrm{C}$ ). However, apart from these regions, the two models agree in the nature of daily maximum changes across our analysis region.

With the exception of the Western Sahara and north-west Mauritania, the typical futureclimate day will have a maximum temperature equivalent to beyond the 95th percentile of present-day conditions (Fig. $2 \mathrm{~g}, \mathrm{~h}$ ). This represents a statistically significant increase beyond the 95th percentile (not shown). Indeed, for almost all of sub-Saharan Africa, typical May daily maximum temperatures in the future climate will be beyond anything presently experienced in CP4-A. In P25, the same conclusion is found over the Sahel, with typical future-climate temperatures exceeding the 95th percentile of present-day values over the Guinea Coast. Figure 2 shows that both CP4-A and P25 project that the future maximum temperatures during May will be beyond anything presently experienced for a large proportion of West Africans, echoing the prior work of Mora et al. (2013).

Figure 3 shows the change in daily minimum temperatures during May. In both models, typical daily minimum temperatures across much of West Africa are around $22-25^{\circ} \mathrm{C}$ in the present climate (Fig. 3a, b), although values are lower over Niger and Cameroon in P25 compared with $\mathrm{CP} 4-\mathrm{A}$. Compared with daily maximum temperatures, minimum temperatures show less meridional heterogeneity across West Africa in the present climate (compare Figs. 2a, b and 3a, b).

Future-climate daily minimum temperatures are projected to increase substantially in both models (Fig. 3c, d), with temperatures exceeding $32{ }^{\circ} \mathrm{C}$ typical for parts of Mauritania, Mali, Niger and Chad in the future within the P25 simulation. Increases in $\mathrm{P} 25$ are typically $1-2{ }^{\circ} \mathrm{C}$ greater across climates than those seen in CP4-A, particularly across Benin, Nigeria, northern Ghana and much of the Sahel. Figure 3c, d implies that there is greater spatial heterogeneity in future-climate typical minimum temperatures than simulated for the present climate; the cause for this difference is beyond the scope of our analysis but could be worth future consideration. Both models show much of West Africa with a projected absolute increase in typical daily minimum temperatures during May of greater than $6{ }^{\circ} \mathrm{C}$ (Fig. 3e, f).

Both models agree that, for all of sub-Saharan Africa, the typical daily minimum temperature during May by the end of the twenty-first century will be beyond any presently experienced value (Fig. 3g, h); this shift is statistically significant beyond the 95th percentile. Coupled with Fig. 2, both CP4-A and P25 project not only a warmer future climate over West Africa during May, but a climate where temperatures that would be considered truly exceptional presently will become standard.

Figure 4 shows the simulated present-day and future-climate maximum temperatures during August on a typical day. There is consistent agreement in the magnitude and spatial variability 


\section{May comparison}

(a)

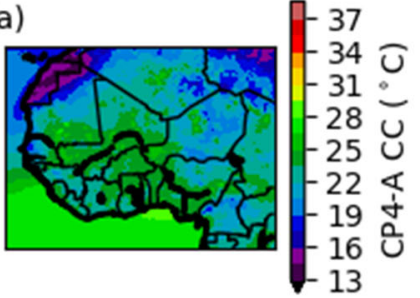

(c)

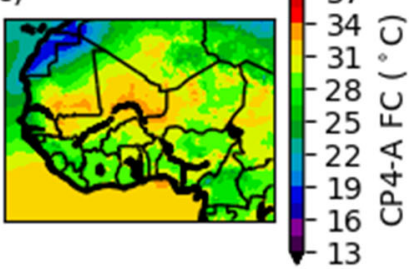

(e)

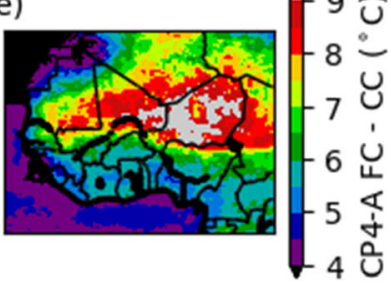

(b)

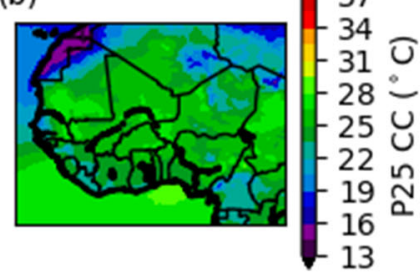

(d)

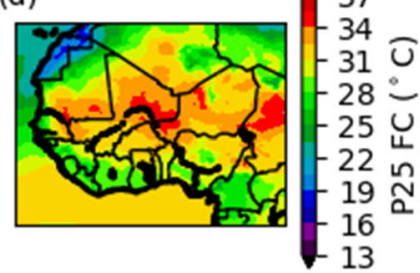

(f)

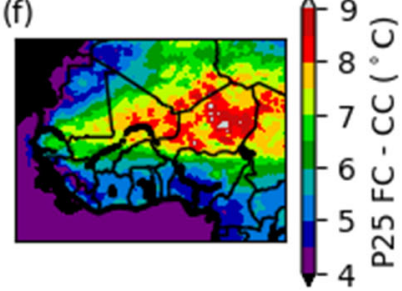

(g)
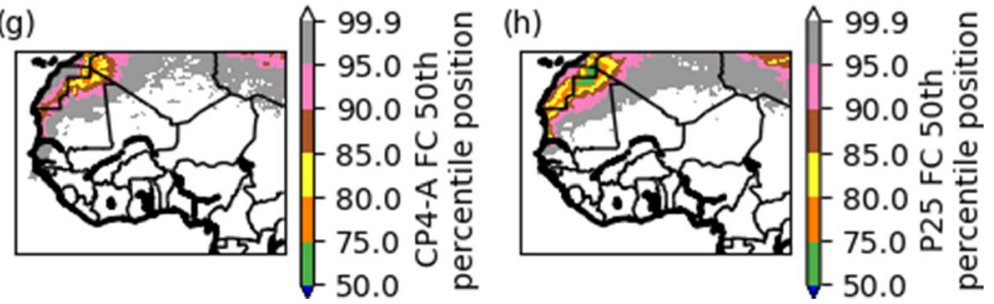

Fig. 3 Comparison of typical daily minimum temperatures during May in the current- and future-climate simulations of CP4-A and P25. a, b The typical (median) daily minimum temperature at $1.5 \mathrm{~m}$ above the surface during May from the CP4-A and P25 current-climate output, respectively, with (c) and (d) showing the same metric for the future-climate model runs. e, f The absolute difference between future- and current-climate typical values for each model. $\mathbf{g}, \mathbf{h}$ The percentile of the simulated current-climate distribution from each model which corresponds to the typical (median) future-climate daily minimum near-surface temperature. White regions in (g) and (h) denote locations where the future typical daily minimum temperature is warmer than $99.9 \%$ of currentclimate values

of daily maximum temperatures across the two models in both the present climate (Fig. 4a, b) and future climate (Fig. $4 \mathrm{c}, \mathrm{d})$. The regional maximum in present-day temperature $\left(>41^{\circ} \mathrm{C}\right)$ located over northern Mauritania, northern Mali, and Algeria extends further south in P25 compared with CP4-A, which could imply a deeper Saharan Heat Low (Lavaysse et al. 2009, 2015 ) in the parameterised convection model. However, outside of this region, the two models 


\section{August comparison}

(a)

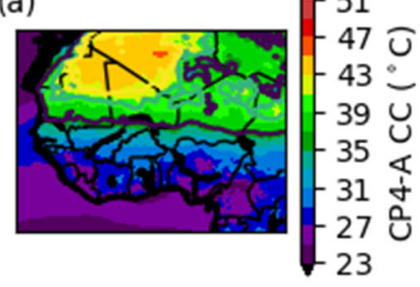

(c)

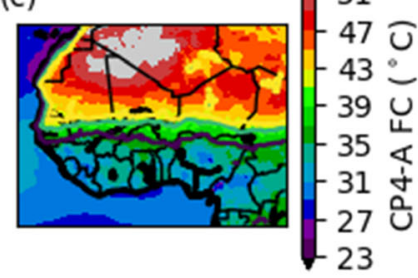

(e)

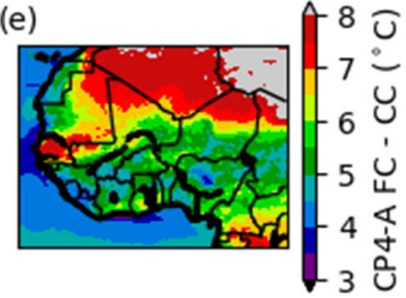

(b)

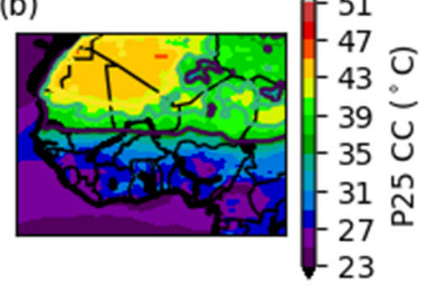

(d)

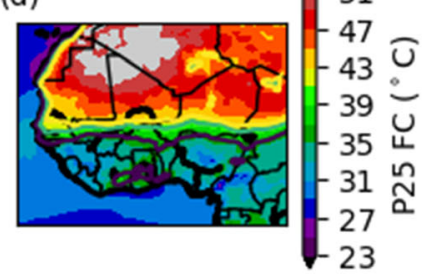

(f)

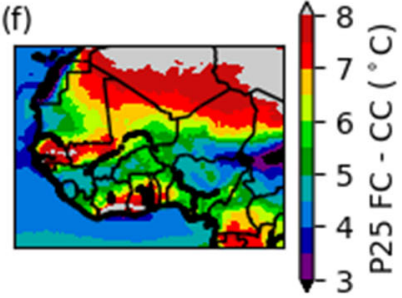

(g)
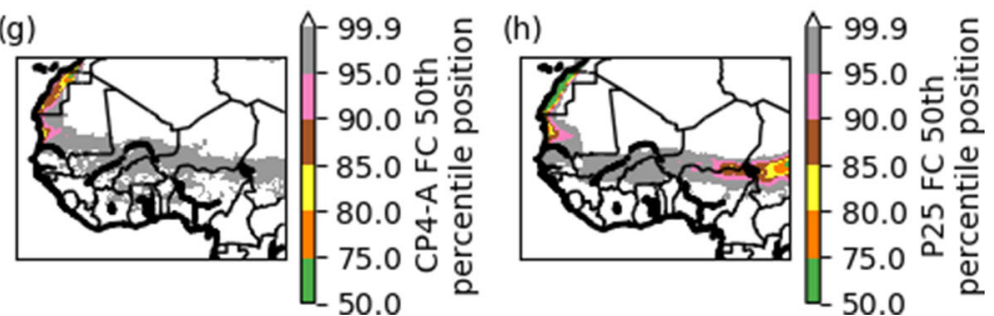

Fig. 4 Analogous figure to Fig. 2, using August typical daily maximum temperatures at $1.5 \mathrm{~m}$

are closely aligned, and show a zonally homogenous, but meridionally heterogeneous distribution in maximum temperatures.

In both future climate simulations, the south-north meridional temperature contrast previously seen in other studies (e.g. Vizy et al. 2013; Fitzpatrick et al. 2020) is also apparent-here in the typical daily maximum August temperatures. Across Burkina Faso, southern Niger, northern Nigeria and south-western Chad, typical temperatures increase by around $3-5{ }^{\circ} \mathrm{C}$ between climates in both models, from approximately $27.5-29$ to $33.5-35{ }^{\circ} \mathrm{C}$ (Fig. 4e, f). Towards the Guinea Coast, greater absolute increases are projected over Ghana and Cameroon in both simulations, although $\mathrm{P} 25$ projects greater increases (of the order of $1-2{ }^{\circ} \mathrm{C}$ ) over the Ivory Coast, Benin and southern Nigeria. However, both models project a substantial increase 
in typical daily maximum temperatures north of the Sahel $\left(>6{ }^{\circ} \mathrm{C}\right)$ with daily maximum temperatures greater than $47^{\circ} \mathrm{C}$ standard across almost all over the Saharan region. Figure 4 is thus consistent with the expectation that the Sahara will heat disproportionately compared with the Sahel under climate change.

With regard to relative changes, Fig. $4 \mathrm{~g}$, h both highlight a narrow latitude band over northern Senegal, southern Mali, Burkina Faso, and the Niger-Nigeria border where the typical future climate daily maximum temperature during August exceeds the 95th percentile of present-climate values. Elsewhere, the typical temperature is beyond the 99.9th percentile of current temperatures. This narrow band aligns with the location of the maximum rain belt over West Africa in the current climate (c.f. Lafore et al. 2011) implying potentially that relative temperature increases during the core Sahelian monsoon month are lower over the region where large-scale rainfall is present. Regardless, Fig. 4 shows typical temperatures in the future that would be considered extreme and potentially high impact from a current-climate perspective.

Current-climate typical daily minimum temperatures are similar during May (Fig. 3) and August (Fig. 5) with temperatures ranging between 19 and $25^{\circ} \mathrm{C}$ across most of the region. However, typical future-climate daily minimum temperatures during August in the future climate exceed $34{ }^{\circ} \mathrm{C}$ for a much larger proportion of the Sahara and north-west Africa compared with May in both models (compared Fig. 3c, d with Fig. 5c, d). Near the Guinea Coast, with the possible exception of the Dalhomey Gap region around Togo and the Ivory Coast, although typical future-climate minimum temperatures do increase during August across climates, these increases are of the order of $4{ }^{\circ} \mathrm{C}$ relative to the $>6.5{ }^{\circ} \mathrm{C}$ increases seen over the Sahara (Fig. 5e, f). Effectively, these increases act to impose a clear meridional gradient in typical daily minimum temperatures across West Africa in the future within both models (Fig. 5c, d). We do not explore the impact of this change on the diurnal cycle on moisture circulation across climates here, but this may be worthy of future research.

Figure 5g, h highlight that both models project typical daily minimum temperatures beyond any currently experienced locally for almost the entirety of our analysis region. Although the local respective change in typical daily minimum temperatures lies beyond the 99.9th percentile for almost all of West Africa, projected future climate values over the Guinea Coast region are comparable with those found over Mali and Burkina Faso in the present climate. Figure $5 \mathrm{~g}$, h thus shows the fundamental difference between the methodology applied here and methods that compare different geographical regions in different climates.

Figure 6 highlights the percentage of future-climate August minimum temperature during August in CP4-A and P25 which exceed the typical present-day maximum temperatures. Over the Sahara, we see that neither model projects future minimum temperatures to exceed the present-day typical maximum temperature. This result is expected given the large difference between daytime and night time temperatures over the Sahara due to sensible heating and radiative cooling. However, across the Guinea Coast and the Sahel, we see that there are future-climate days with a minimum temperature in excess of the present-day maximum temperature on the median day. Within Sahelian countries, the frequency of this occurrence is relatively modest but non-negligible (around 5-15\% of days). Over parts of Guinea, Sierra Leone, Nigeria, and Cameroon, over $40 \%$ of future-climate days meet this criteria, with some regions of Nigeria and Cameroon showing rates higher than 70\%. P25 tends to project a higher percentage of future-climate days that meet our criteria, which is associated with the relatively greater absolute increase in future-climate minimum temperatures, particularly over Cameroon (Fig. 5f). Figure 6 shows that, for certain regions of West Africa, a considerable number of future-climate days will have hotter nights than a typical day in the present. 


\section{August comparison}

(a)

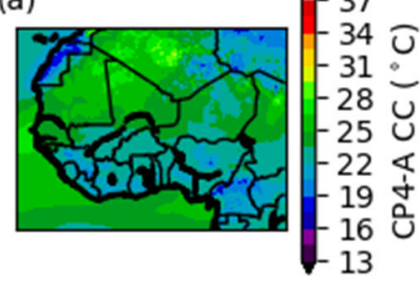

(c)

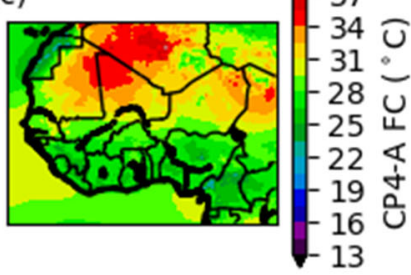

(e)

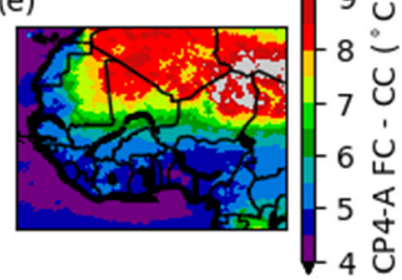

(b)

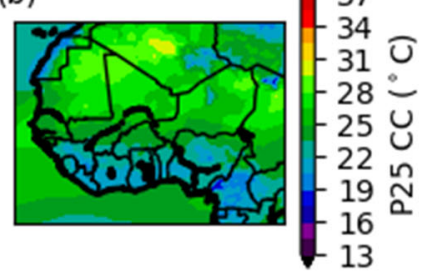

(d)

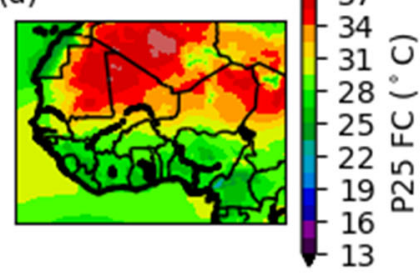

(f)

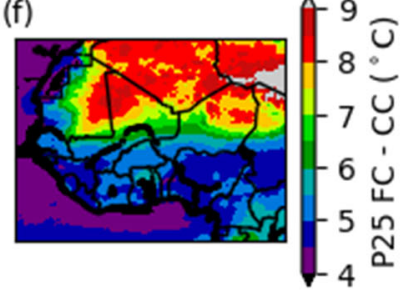

(g)
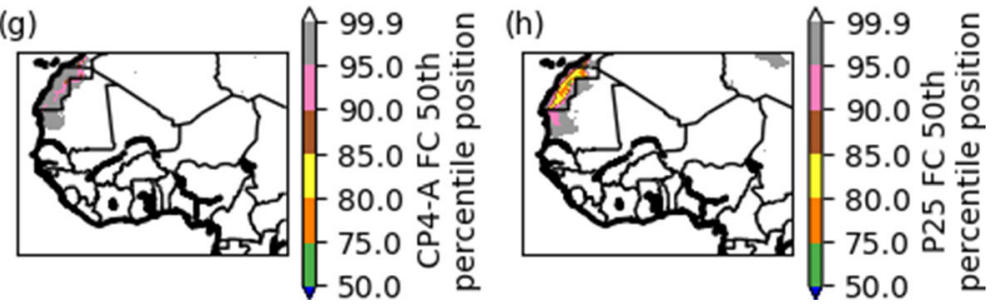

Fig. 5 Analogous figure to Fig. 3, using August typical daily minimum temperatures at $1.5 \mathrm{~m}$

Figure 7 presents an analogous result to Fig. 4g, across the bias-corrected CMIP5 ensemble. Note that all models only show changes for land points. Across the Sahel, the median futureclimate daily temperature maximum lies beyond the 99.9th percentile value simulated in the current climate in 22 out of 29 models. The exceptions are BNU-ESM, CNRM-CMS, MIROC ESM-CHEM, MIROC ESM, MIROCS, NorESM1_M, and inmcm4. Of these seven models, CNRM_CMS, MIROCs, NorESM1_M, and inmem4 do project future median daily maximum temperatures towards the upper end of present-day values. Over the Guinea Coast, a similar result is seen with the majority of models simulating median future-climate values beyond the 90th percentile of present-day values. However, over the Sahara, all models simulate future median daily maximum temperatures during August beyond all presently 
(a)
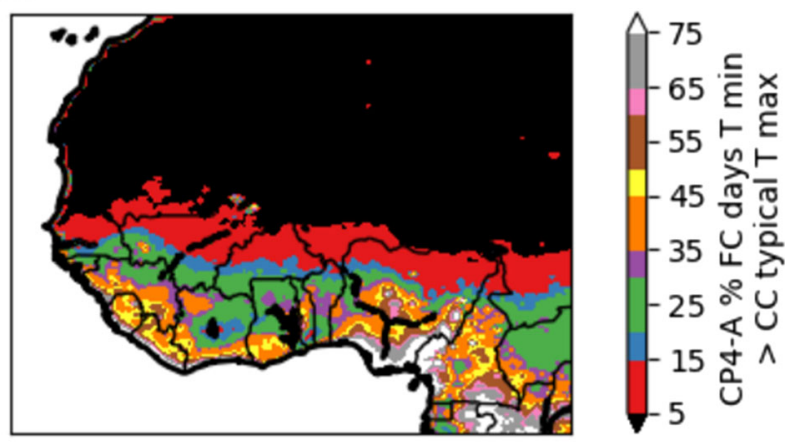

(b)

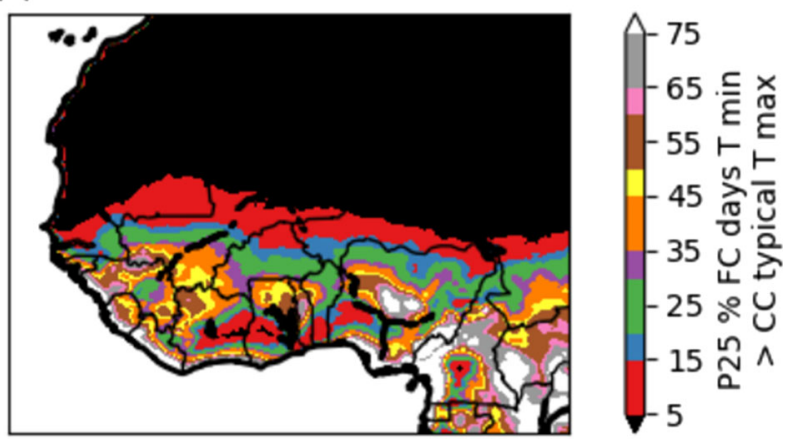

Fig. 6 Identification of regions where future-climate minimum temperatures during August may be warmer than typical current-climate daily maximum temperatures. a, $\mathbf{b}$ The percentage of future-climate August days that have a minimum temperature greater than or equal to the current-climate maximum temperature on a typical day within CP4-A and P25, respectively. Black regions denote areas where less than 5\% of future-climate days meet these criteria

simulated values. Figure 7 implies that our findings for CP4-A and P25 are robust compared with a larger available ensemble of climate projections. We find a similar result for temperature maxima in other months, and for temperature minima (not shown).

\subsection{Changes in rainfall intensity and agronomic onset}

Figure 8 compares the median daily precipitation total on all days with at least $1 \mathrm{~mm}$ of rainfall across climates. We have included all of our analysis region in Fig. 8 but note the caveat that there are very few qualifying rainfall events in either model/climate across most of the Sahara (not shown). We also note that there are fewer rain events across West Africa in the futureclimate simulations (Kendon et al. 2019) and fewer mesoscale convective systems (Fitzpatrick et al. 2020) compared with the current climate.

Noting the different scaling, the typical rainfall rate simulated in P25 is lower than that found in CP4-A across all of the Sahel in both the current climate (Fig. 8a, b) and future climate (Fig. 8c, d). This finding is expected from prior comparisons of CP4-A and P25, although we do note that CP4-A may overestimate the rainfall as well particularly over high topography (Berthou et al. 2019; Crook et al. 2019; Kendon et al. 2019). Here, we focus on the 

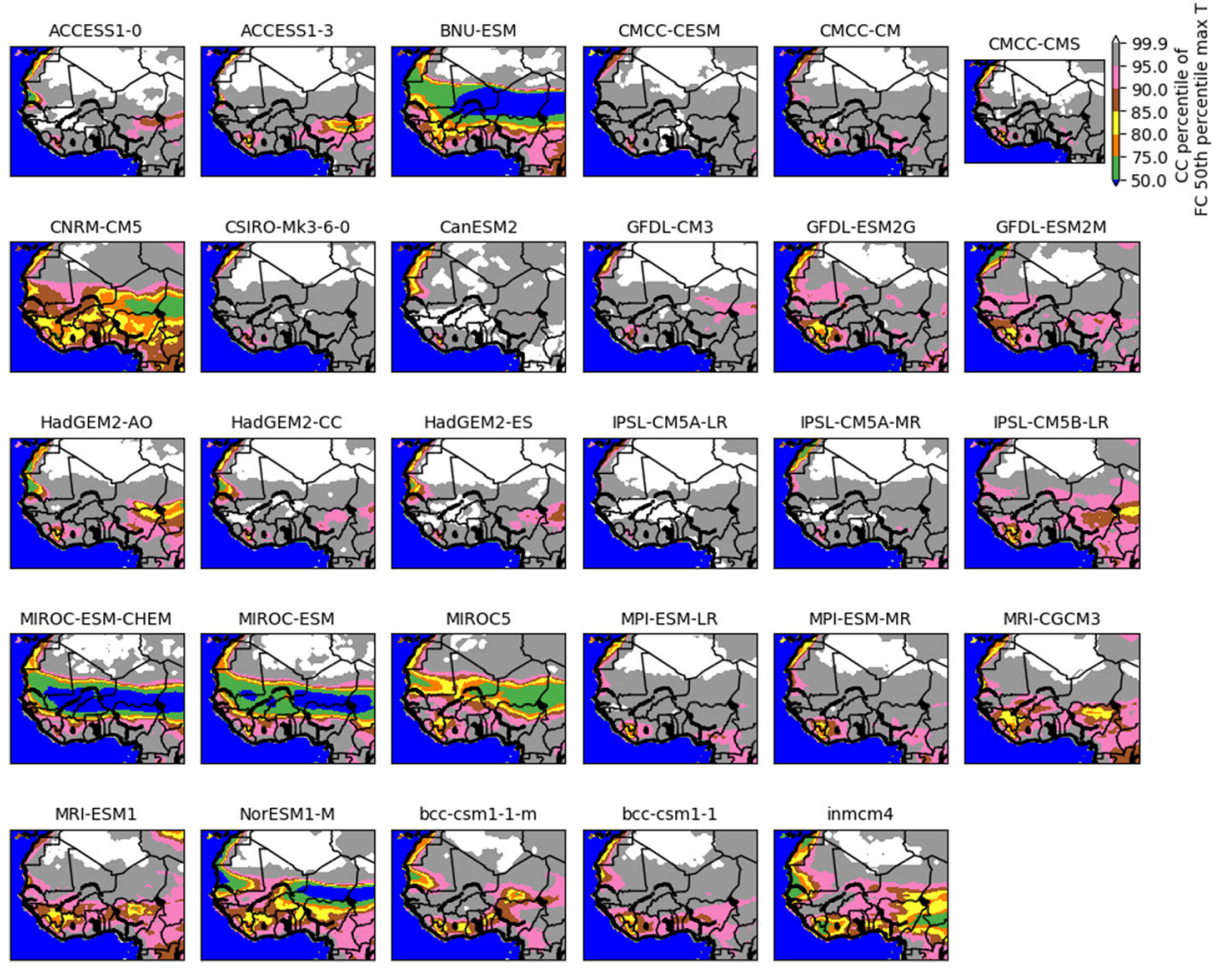

Fig. 7 Recreation of Fig. 4g using the full avaiable bias-corrected CMIP5 ensemble from Famien et al. (2018). Current-climate median temperature values are taken from 1980 to 2000, with future-climate values taken from 2080 to 2100 . Note that the bias-corrected dataset only includes continental land points across Africa

spatial nature of changes in typical rain rates and the relative change locally across climates within both models.

Within CP4-A, typical storm rain rates show a degree of zonal homogeneity across West Africa (Fig. 8a). The highest rates over land are modelled over Guinea, Sierra Leone, and Liberia (>80 mm/day), with values ranging from 60 to $80 \mathrm{~mm} /$ day found over the rest of the Guinea Coast and sub-Sahelian West Africa. Over the Sahel, typical storm rain rates range from 40 to $60 \mathrm{~mm} /$ day for most of the region, with the exception of southern and coastal Senegal where typical rates of $60-80 \mathrm{~mm} /$ day are found. P25 simulates a similar maximum over Guinea (40-45 mm/day - Fig. 8b), however does not highlight a maxima over Sierra Leone and Liberia, and also has greater zonal heterogeneity in typical rain rates across the rest of the Guinea Coast. P25 captures a northwest-southeast tilt in the contours of typical day rain rates in the current climate, consistent with that see for CP4-A. This tilt is similar to presentday observations of the Inter-tropical Front, and the slope of the 1-mm/day and 4-mm/day isohyets observed in Lélé and Lamb (2010).

If both future-climate simulations, there is a northwards shift in the typical day rain rates (Fig. 8c, d), most pronounced over southern Mauritania and central Mali in CP4-A. Relatively intense typical rain rates for each model (50 mm/day in Fig. 8c for CP4-A, 25 mm/day in Fig. 
(a)

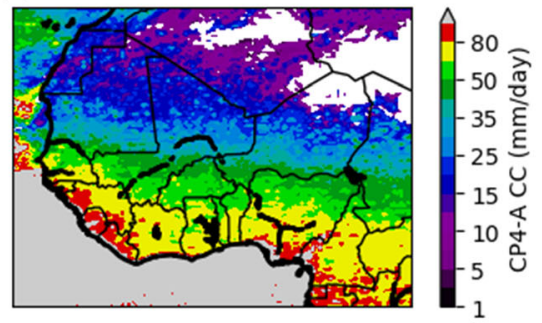

(c)

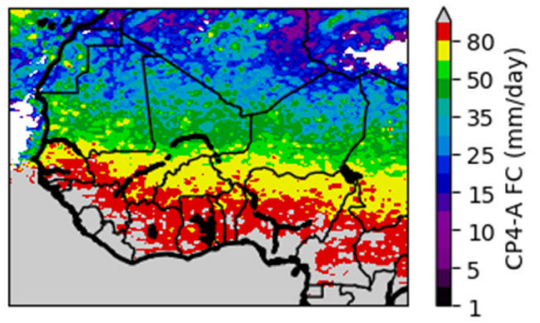

(e)

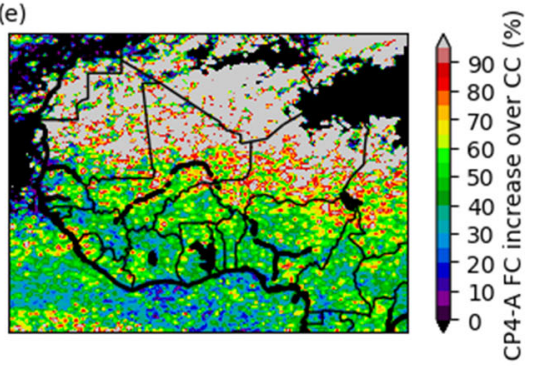

(g)

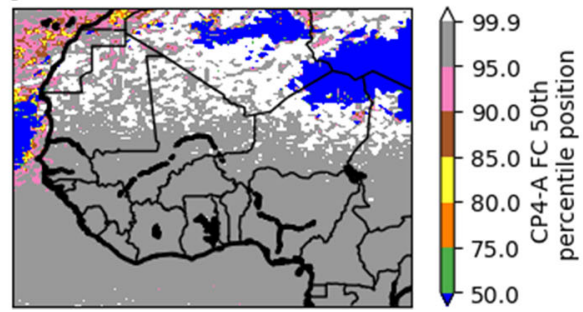

(b)

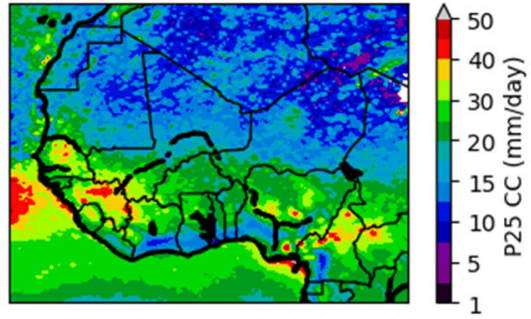

(d)

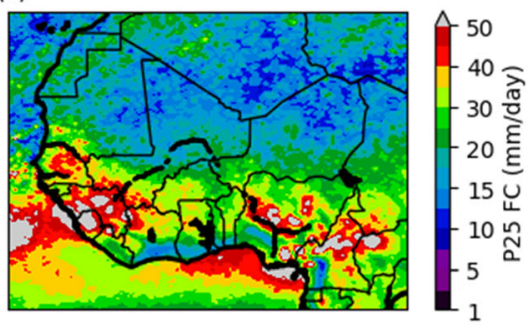

(f)

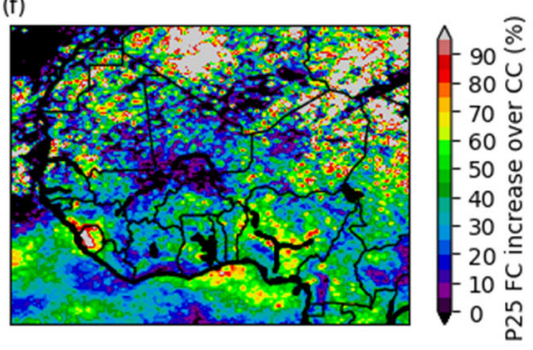

(h)

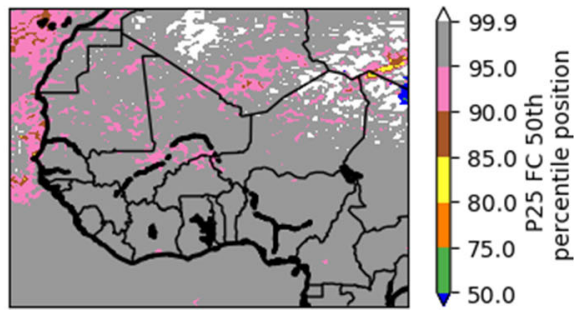

Fig. 8 Comparison of typical daily precipitation rate across all days with at least $1 \mathrm{~mm}$ of rainfall in the currentand future-climate simulations of CP4-A and P25. a, b The typical (median) daily precipitation rate from the current-climate CP4-A and P25 output, respectively, with (c) and (d) showing the same metric for the futureclimate model runs. e, $\mathbf{f}$ The percentage change in typical daily rainfall rates between the future- and currentclimate simulations for each model. $\mathbf{g}, \mathbf{h}$ The percentile of the simulated current-climate distribution from each model which corresponds to the typical future-climate rainy day precipitation rate. White regions in (g) and (h) denote locations where the daily rainfall rate of a typical future-climate rainy day exceeds that of $99.9 \%$ of current-climate rainy days 
$8 \mathrm{~d}$ for P25) penetrate further north in the simulation with explicit convection compared with the parameterised-convection counterpart model, particularly over Mali and Niger.

Relatively high rainfall rates for typical storms in CP4-A (>60 mm/day) are seen over much of the Sahel and Guinea Coast, with local percentage increases in typical storm rain rates of around 50\% found for most of sub-Saharan West Africa (Fig. 8e). This increase is consistent with Fitzpatrick et al. (2020), who find an average $43 \%$ increase in rain rates of mesoscale convection systems across the Sahel between the current and future-climate CP4-A simulations. By contrast, P25 projects east-west heterogeneity in the percentage increase of typical storm rain rates, with the smallest increases (0-20\%) seen over southern Mali. Figure 8 shows a difference in the magnitude and spatial variability in precipitation projections across our two models that are not present in projections of temperature changes.

Despite the spatial disagreement in precipitation rates across CP4-A and P25, we find that both models project the rain rate associated with a typical future-climate event over sub-Saharan Africa will be beyond the 95th percentile of present-day values (Fig. 8g, h). Despite the differences in absolute and percentage changes seen across models, there is agreement that currently considered extreme rain events (i.e. $>$ 95th percentile events) will be typical in the future.

Figure 9 shows the average date of the agronomic onset (or the onset of persistent local rainfall) across the Sahel. Given that agronomic onset occurs at most once per year per location, we do not analyse the relative change in onset dates across climates as we do not consider the sample sizes large enough to given meaningful insight. Instead, we comment below on the spatial distribution of onset dates and how this pattern changes across climates.

In both simulations of the current climate (Fig. 9a, b), we see a southwest-to-northeast progression of agronomic onset. The earlier mean current-climate onset dates (1-15 June) are found over northern Guinea, southern Mali, and southern Burkina Faso in CP4-A (Fig. 9a), with P25 simulating these earlier onset dates farther east towards northern Benin (Fig. 9b). A band of the Sahel has mean onset dates around 1-15 July in both models including northern
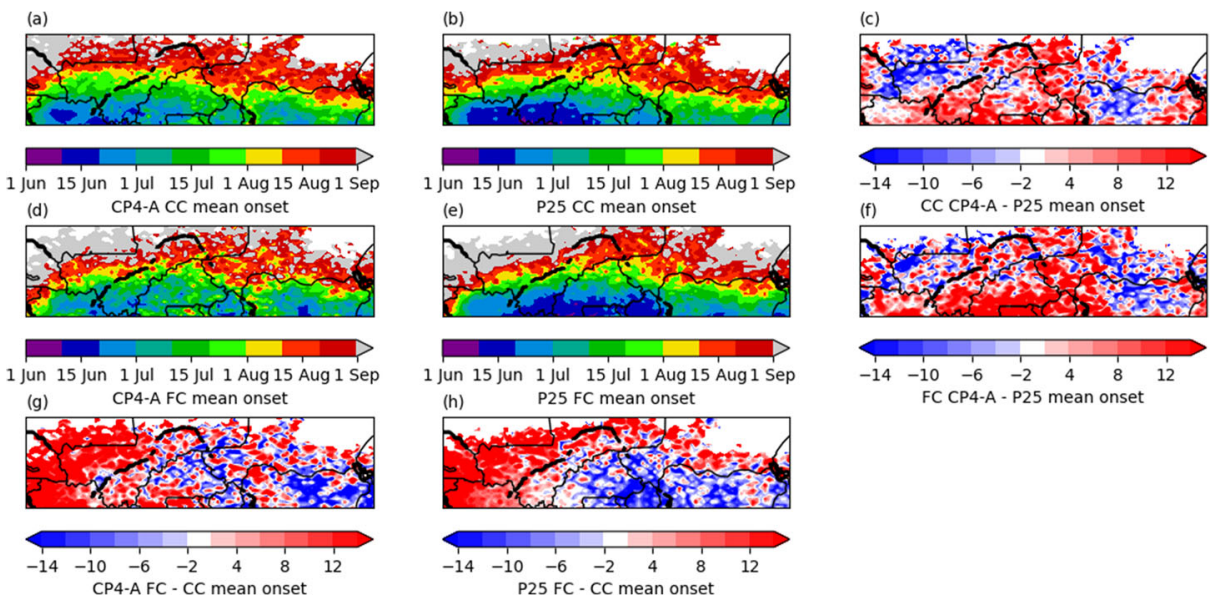

Fig. 9 Change in mean agronomic monsoon date over the Sahel across climates. a, b The mean agronomic monsoon onset date across the Sahel from the current-climate CP4-A and P25 simulations, respectively, with (c) showing the difference between (a) and (b). d-f The same data for the future-climate simulations. $\mathbf{g}$, $\mathbf{h}$ The difference in mean onset date between the future climate and current climate for each model. In (a), (b), (d), and (e), white regions denote locations where the agronomic onset criteria are not met for more than 5 of the 10 years of model output. See Table 2 for definition of agronomic monsoon onset 
Burkina Faso, southwest Niger, and most of Nigeria. The latest onset dates are found across northern Senegal, southern Mauritania, and central Mali and Niger in both models. Overall, the spatial pattern of onset progression is consistent between the two simulations; however, we note that CP4-A simulates later mean onsets over Burkina Faso and central Mali of the order of 10-12 days (Fig. 9c) and earlier onsets by approximately the same timeframe around Senegal, south-west Mali, and parts of northern Nigeria. It has been posited before that the poor representation of early season MCSs in parameterised-convection models lead to inaccuracies in local onset dates (Fitzpatrick et al. 2016, Appendix B). The spatial pattern of mean onsets in the current climate within both models is similar to that found in observations (Fitzpatrick et al. 2015) and appears more realistic than in prior versions of the Met Office seasonal forecasting model (Fitzpatrick et al. 2016, Appendix B).

With the exception of later future-climate onsets over southern Mali and southern Burkina Faso in CP4-A, we see agreement between models in the future changes in local onset dates (Fig. 9d, e). Within both model projections, there is evidence of an east-west dipole in relative onset timings across climates, with later onsets (up to two weeks later) projected across the Western Sahel, and earlier onsets of a similar temporal magnitude projected across the Eastern Sahel in the future (Fig. 9f, g). This dipole in the change in onset dates is similar to the projected change in annual and seasonal precipitation totals under global warming (Biasutti 2013; James et al. 2014), and to changes in relative humidity (Kendon et al. 2019; Fitzpatrick et al. 2020). Alongside prior work, Fig. 9 suggests that not only will the western Sahel become relatively drier in the future climate, but it will have a later onset of persistent rainfall.

Figure 10 highlights the change in the standard deviation of simulated agronomic onset dates across climates. We first note that the agronomic onset has a higher inter-annual variability than regional onset metrics (Sultan and Janicot 2003; Marteau et al. 2009; Fitzpatrick et al. 2015), and values of 14-21 days over Burkina Faso and Niger are found in satellite rainfall observations (Fitzpatrick et al. 2015). Nevertheless, Fig. 10 shows an apparent shift across almost the entire Sahel, with the exception of Senegal and northern Benin, towards higher inter-annual variability of onset timing under climate change. Broadly, this pattern is

(a)

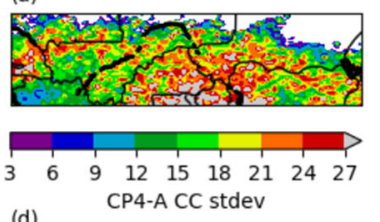

(d)

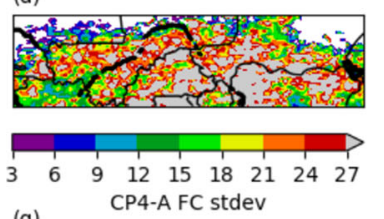

(g)

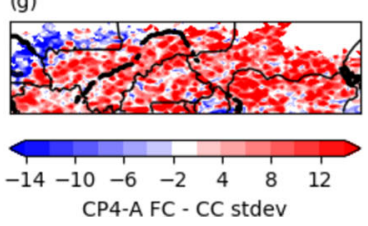

(b)

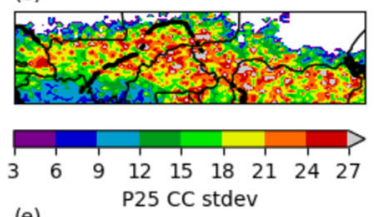

(e)

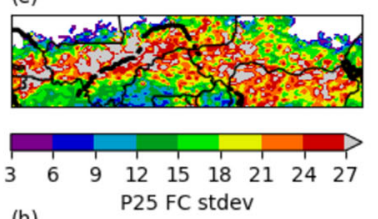

(h)

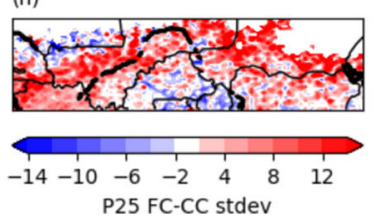

(c)

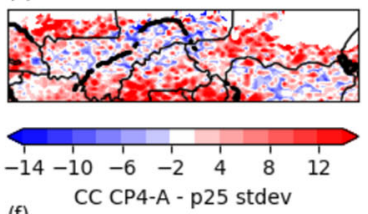

(f)

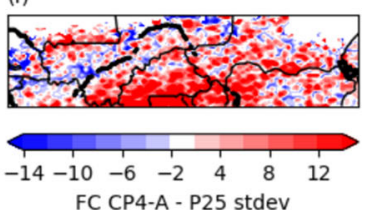

Fig. 10 Analogous figure to Fig. 9, but evaluating differences in the standard deviation of agronomic monsoon onset at each grid point 
(a)

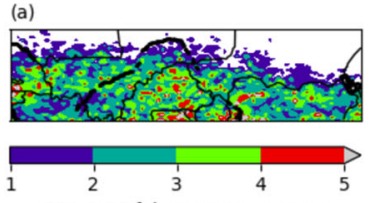

(d) (b)

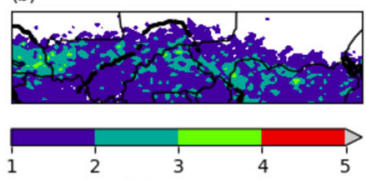

(e)

P25 CC false onsets per year

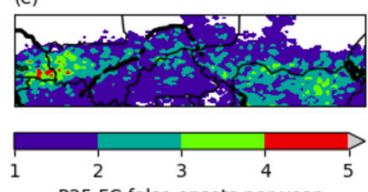

(h)

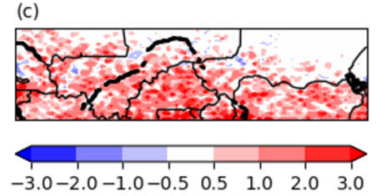

CC CP4-A - P25

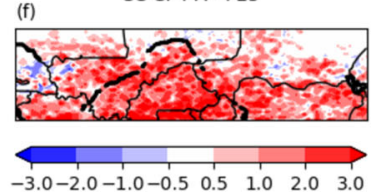

FC CP4-A - P25 (g) CP4-A FC false onsets per year
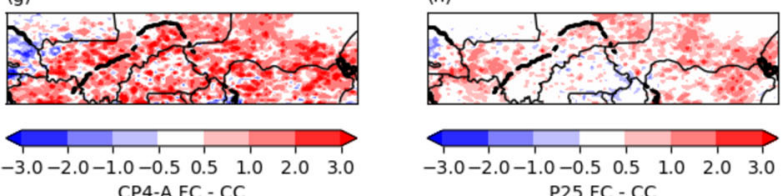

CP4-A FC - CC

P25 FC - CC

Fig. 11 Analogous plot to Fig. 9, but displaying the change in the average number of false agronomic onsets per year for each grid point. See Table 2 for the definition of false onset

also recreated in P25; however, this simulation projects a reduction in variability over Burkina Faso across climates. The drivers of agronomic onset are not well understood, although regions of consistent inter-annual variability have been identified across the Sahel (Fitzpatrick et al. 2016). Better understanding of the cause of the relative delay and increased variability in onset dates across climates deserves increased future attention.

Finally Fig. 11 presents the average number of false onsets per year in both models and across climates. CP4-A simulates more false onsets on average per year in both climates compared with P25 (Fig. 11c, f), which is associated with an increased number of isolated early season rainfall events in the explicit convection model (not shown). As agronomic onset is an underexplored subject, the nature, frequency and importance of these early season systems requires further understanding both in the present climate and in future projections. Across climates, we see an increase of up to 2 extra false onsets per year across the Sahel in CP4-A (Fig. 11g), with a smaller increase of around 1 extra false onset per year projected in P25 (Fig. 11f). Collectively, Figs. 9-11 present projections of later, more variable agronomic onset across much of the Sahel with an increased risk of false onset. The socioeconomic risk associated with these changes, particularly false onset rate and inter-annual variability are not easy to speculate on, as these events are experienced on a sub-seasonal forecasting timescale and thus their impact will be intrinsically tied to the value of future forecasts (Murphy 1993). However, across all figures, CP4-A and P25 both point to a future climate over West Africa where present-day extremes are common occurrences.

\section{Discussion}

CP4-A and P25 highlight a drastic change in the temperature extremes projected on a typical future day relative to the present climate, as well as a substantial change in the relative intensity of the typical precipitation event. As with projections of the magnitude of climate change over West Africa, such as those presented above, interpretations of climate change impacts vary due 
to the cascade of uncertainty in simulating adaptation responses (Wilby and Dessai 2010). However, if projected changes within an isolated feasible future-climate scenario are considered without assumptions of adaptation strategies, it is possible to highlight issues that would need to be addressed through such strategies should the projections become a reality. The discussion provided below aims to highlight some specific concerns that could arise under the future presented by CP4-A and P25. We note that the list of potential impacts discussed below is not comprehensive. It is important to be clear about the intentions and limitations of the discussion provided here. Our intention is to highlight some key socioeconomic challenges currently present over West Africa for which the effects could be magnified under the feasible future projected by CP4-A and P25. The authors additionally acknowledge that important mitigation and adaptation measures are being considered and undertaken to tackle the impact of climate change related impacts over West Africa, and thus our projections and implications discussed should not be considered specific prognostications, but as indicative of potential impact. Finally, we are aware that, although our analysis focusses on climate change, this challenge is merely one of many co-existing factors that can inhibit socioeconomic development within the Sahel, and in some cases may not be the primary barrier to sustainable improvement (Mertz et al. 2009).

\subsection{Potential impact of changes on crops}

Agricultural related risks are of particular interest given the self-sufficient nature of the West African food economy, and the difficulty in implementing adaptation methods in this field, for example due to personal dietary preferences, or the length of time they take to implement (Challinor et al. 2016). Crops can be particularly susceptible to changes in heat and available water. For example, crops experience heat stress when they encounter temperatures above the range to which they are adapted (Barnabás et al. 2008). The impact of heat stress on crop growth and development is a function of the magnitude of the temperatures they are exposed to, the duration over which these temperatures persist and the speed at which temperatures depart from normality (Porch and Hall 2013). The temperature thresholds above which crops experience heat stress differs by species (Porter and Gawith 1999; Luo 2011; Sánchez et al. 2014), as does the sensitivity to duration (Prasad et al. 2017) and the rate at which acclimation is possible. An over-arching understanding of the duration of high temperatures required for heat stress to occur across plants remains at the frontier of research in the plant sciences.

Table 2 Critical temperature thresholds for different regionally important field crops taken from two separate studies

\begin{tabular}{llr}
\hline Crop & $\begin{array}{l}\text { Damaging temperature } \\
\text { threshold }\left({ }^{\circ} \mathrm{C}\right) \\
\text { (Prasad et al. 2017) }\end{array}$ & $\begin{array}{l}\text { Mean lethal temperature } \\
\text { limit }\left({ }^{\circ} \mathrm{C}\right) \\
\text { (Sánchez et al. 2014) }\end{array}$ \\
\hline Groundnut & 36 & $46 \pm 2.9$ \\
Maize & 35 & $42.9 \pm 0.7$ \\
Rice & 35 & $47.5 \pm 0.5$ \\
Wheat & 32 & \\
Sorghum & 38 & \\
Millet & 40 & \\
\hline
\end{tabular}


Under the projections of temperature change from CP4-A and P25, crop diversity across West Africa could be reduced by necessity in the future climate across many regions. Parts of northern Senegal, southern Mali, and southern Niger experience daily maximum temperatures that exceed $38^{\circ} \mathrm{C}$ in August. A similar finding exists for July and September (not shown). This temperature exceeds the threshold for irreversible crop damage or even total crop destruction thresholds during the reproductive stage for the major crops grown in these regions except groundnut, sorghum, and millet (Table 2) (Sánchez et al. 2014; Prasad et al. 2017). We note here that Sánchez et al. (2014) also investigate damaging temperatures, with values comparable with Prasad et al. (2017). These regions will therefore be less suitable for maize, rice and wheat cultivation than they are today. This simple suitability based analysis is supported by the findings of more complex approaches using process-based crop models, which integrate the impacts of changing temperatures, rainfall and carbon dioxide (e.g. Challinor et al. 2014, 2015, 2016). In a recent review of climate impacts on agriculture in West Africa, Sultan and Gaetana (2016) found that although there is a large spread in modelled outcomes and that outcomes vary regionally, robust evidence of overall negative impacts on crop yields emerged.

Noting the dominance of temperature impacts on crop yield in the Sudanian and Sahelian savannah regions, Sultan et al. (2013) point to the importance of breeding crops capable of withstanding the effects of global heating. This adaptation strategy is emphasised in a number of studies. Guan et al. (2017) use crop models to explore the potential of five plausible adaptation options for Sorghum in West Africa and find that increased tolerance to heat during grain filling is the most effective. Parkes et al. (2018) find that the impacts of global heating on maize yields in West Africa under RCP8.5 is less severe when simulating a genotype that is resistant to the impacts of heat stress during flowering.

The process of conventional breeding for heat tolerance involves selectively crossing heattolerant cultivars with commonly grown cultivars that meet regional dietary and market preferences. Whilst this may be an effective strategy for some crops, knowledge of existing genetic diversity in many plants remains limited (Driedonks et al. 2016). The extent to which it is possible to breed crops that are able to cope with the conditions projected in the RCP8.5 scenario remains uncertain.

Breeding field crops better able to withstand high temperatures during flowering would not automatically account for the impact of projected high night-time temperatures. The large rise in minimum temperatures described in this study could also affect crop productivity by increasing maintenance respiration, which lowers net growth (Mall et al. 2006). For example, a narrowed diurnal range of temperatures decreases production of non-structural carbohydrates leading to a loss of grain weight and quality in rice (Jagadish et al. 2015).

\subsection{Potential impacts of projected changes on livestock}

Concerns regarding the impact of increased temperature also extend to livestock. For example, although native cattle within tropical regions, zebu cattle (Bos indicus), have evolved to survive in high temperatures through evolutionary traits such as increased capacity for heat loss (Hansen 2004), future stressors may impact the sustainable rearing of these animals. Studies have shown that zebu cattle are better equipped to reproduce and survive in hot regions (Seif et al. 1979; Eberhardt et al. 2009; Charoensook et al. 2012). However, whilst zebu cattle can adapt to high temperatures through enhanced perspiration, this process requires increased water uptake by the animals (Seif et al. 1979; Aggarwal and Upadhyay 2013). The projected trend towards more intermittent, but intense precipitation events across West Africa could pose 
a problem for rearing livestock particularly in nomadic communities; however, the extent of this impact will depend on many factors including changes in water resource management. Further, the nutritional rate of livestock by-products decreases under increased exposure to high temperatures (Abdalla et al. 1993; Cooke et al. 2020). An increased population could require more livestock to be reared for food without social changes in dietary patterns (Cooke et al. 2020), further placing stress on water resources.

However, it is important to note that studies on livestock adaptability to high temperatures almost exclusively do not consider temperatures at the levels seen in Fig. 3 . Interpretations of projected changes within CP4-A and P25 on livestock require a degree of extrapolation and will also be affected by breeding, husbandry, and dietary changes through the twenty-first century. Regardless, it is evident that increased temperatures can have at least a negative impact on water resources necessary for livestock practices within the Sahel. However, not all impacts of projected climate change on livestock are negative. For example, CP4-A and P25 project a decrease on the frequency of cold night-time temperatures (not shown for all months), which have previously been identified by stakeholders as high-risk events for animals (Visman et al. 2017).

\subsection{Potential impact of projected changes on psychological and physical health}

To the authors' knowledge, there are few climate science papers focussed on West Africa (or indeed globally) which expand their scientific findings to the field of mental health challenges. Given expanding public interest in mental health over recent decades, and the stacking nature of other climate stressors on mental health, we consider it of interest to provide a discussion on this topic within the context of climate change and weather extremes with the aim of spurring future co-production of research within this field.

The study of the impact of climate change on psychological health is a fast-expanding topic in the broader scientific literature. For example, Vins et al. (2015) provide a meta-study of contemporary literature identifying direct and indirect ways through which damaging dry spells or droughts, which become more frequent in CP4-A (not shown) can affect the economic, social, and mental wellbeing of affected communities. However, we note that none of the studies examined within Vins et al. (2015) were directly related to West Africa. Indeed, the authors could not find dedicated studies of climate change and mental wellbeing for communities living in West Africa, highlighting an important avenue for future research. Subsequently, we provide discussion drawing from the wider literature whilst stressing there is a need for more investigation of this evolving subject both globally, as argued by Bourque and Willox (2014), Hayes et al. (2018), and Cianconi et al. (2020) among others, and specifically for West Africa.

Rising temperatures have been linked to an increase in mental health concerns (Reiser 2017; Hayes et al. 2018), with tangible links between a more varying climate with respects to temperature and mental stress identified (Willox et al. 2013; Reiser 2017; Hayes et al. 2018). Further studies have identified long-lasting negative mental health impacts (such as posttraumatic stress disorder) associated with natural disasters, as well as temperature and water stress and degradation of local ecosystems (Ginexi et al. 2000; Norris et al. 2002, 2004; DeSalvo et al. 2007; North and Pfefferbaum 2013; Cunsolo and Ellis 2018; Marshall et al. 2019; Zenko and Menga 2019). The more extreme future-climate typical conditions projected in CP4-A and P25 could amplify the frequency of damaging HIW events along the lines presently observed (Tarhule 2005; Di Baldassarre et al. 2010; Nka et al. 2015; Wilcox et al. 2018; Panthou et al. 
2014, 2018; Taylor et al. 2017; Tazen et al. 2018), and thus increase mental stress for some people living in West Africa. However, there is still a need to improve identification of mental health identifiers and to separate the attributable responsibility of HIW events within such studies (North and Pfefferbaum 2013; North 2014) and incorporate adaptation assessments with regard to mental health (Hayes et al. 2018).

Berry et al. (2010), Fig. 2) provide a framework through which the cultural, economic, social, developmental, and environmental aspects of climate change can affect mental health. Considering how changes such as those projected in CP4-A and P25 will affect mental health along the framework of Berry et al. (2010) naturally carries a degree of speculation. In part, this fact is because climate change is not the only factor that affects mental health (Padhy et al. 2015; Trombley et al. 2017), and the impacts of HIW-related disasters may vary by other factors such as gender (e.g. Viswanath et al. 2013; Manning and Clayton 2018) or economic standing (Ginexi et al. 2000). Nevertheless, the implication of typical future weather conditions towards the extreme end of presently experienced conditions presented here for CP4-A and P25 suggests that an increase in the direct, indirect, and psychosocial impacts of climate change on mental health (Doherty and Clayton 2011) is highly likely without mitigating the scale of climate change over the region.

The impact of HIW extremes on physical health is also a subject of extensive research (e.g. Moran et al. 1999; Patz et al. 2008; Smith et al. 2014; Serdeczny et al. 2017; Wilson 2017), with specific links between higher temperatures and mortality found in West Africa (Azongo et al. 2012; Egondi et al. 2012). As with psychological impacts, the potential for negative health effects from rising temperatures, for example, differ across age groups (Miescher and Fortney 1989; Meade et al. 2020) and physical health (Havenith and van Middendorp 1990). There can be further risk associated with likelihood of exposure (such as performing work in unsheltered, non-temperature-controlled environments) or access to provisions that can help regulate body temperature or hydration levels. It is important to note that these challenges are not caused by climate change per say - as they presently exist in many African nations (for example, according to the charity Water Aid, almost half of people in Burkina Faso do not currently have reliable access to clean water).

Our results compliment the findings of Mora et al. (2017), Fig. 3), who highlight that regions of West Africa will frequently experience lethal temperatures on a regular basis in the future. We additionally highlight that there are many other potential health-related impacts beyond the scope of our study to comment on, such as changes in dust uplift and respiratory conditions. However, we are confident in stating that the change in typical conditions over West Africa projected by CP4-A and P25, particularly temperature changes, imply a higher risk of weather-related mortality by the end of the twenty-first century.

\section{Conclusions}

In the current climate, extreme temperature or precipitation events, at both ends of the scale, can have strong, negative impacts on a population with limited means to adapt to said extremes. The relative frequency of events considered by today's standards to be "extreme" in the future climate helps determine the frequency of high-impact events that can threaten the West African populace's development goals.

In this article, we provide a communication on one possible realisation of climate change in user-relevant metrics, by showing what a median day in the future climate may look like with 
respect to current variability and extremes. We believe that this method can be used alongside other future-climate projection studies to provide information in multiple ways, thus hopefully increasing public engagement in climate science.

Within feasible projections for the end of the twenty-first century, we conclude that HIW events by contemporary standards become regular occurrences over West Africa. Specifically, we highlight the following outcomes:

(1) Future median temperature maxima and minima often lie beyond the most extreme current-climate temperature values.

(2) Across parts of coastal West Africa (particularly Nigeria and Sierra Leone), at least half of future-climate days have a minimum temperature higher than the median currentclimate maximum temperature.

(3) Future-climate median temperatures lie at or beyond the critical temperature thresholds for many staple crops grown in West Africa reducing the number of feasible crops that can be grown in the region.

(4) Median rainfall on days with at least $1 \mathrm{~mm}$ of accumulated rain increases by $>50 \%$ in CP4-A with smaller increases found for P25. This median future wet-day rainfall exceeds the 95th to 99th percentiles of current-climate values in both models.

(5) Onset changes show earlier onset in the eastern Sahel in the future climate, with later onset in the western Sahel. However, given the increase in regularity of extreme temperature events in the future, changes in onset may be, relatively, less important. Additionally, across almost the entire Sahel, the inter-annual variability of onset date increases with climate change.

(6) The frequency of false onsets increases across West Africa in both models and are particularly more frequent in the future-climate CP4-A simulation.

In terms of the relative intensification of local typical temperature and rainfall metrics, CP4-A and P25 show good agreement across almost all cases studied. This includes the relative intensification of typical precipitation rates, despite the absolute rainfall rates simulated by parameterised convection models being known to underestimate observations. We believe that using relative intensification there is a robust signal across different types of climate models. Whilst convection-permitting models give improved representation of convection, and more realistic rainfall values over West Africa (Berthou et al. 2019), from a relative increase viewpoint, less computationally expensive models could provide very similar climate change information for decision makers.

The preponderance of currently considered "extreme" events in the future-climate scenarios presented here stresses the need for climate change adaptation and mitigation to reduce the risk of negative consequences for stakeholders in West Africa. Here, we have highlighted contemporary literature looking at the potential consequences of more-frequent HIW events on agricultural, livestock, and mental health concerns. Mental health in particular is a subject that is not widely broached in climate science research when considering the effects of climate change on people. Given the added strain that climate change can have on other socioeconomic factors, we believe that mental health deserves greater understanding and recognition within co-production research regarding global warming and climate change.

The results of this paper can aid knowledge exchange partners and other branches of research in exploring realistic adaptation strategies in a co-production environment. It is our hope that framing future-climate scenarios in the manner we have presented can provide easy- 
to-disseminate evidence which may help a collaborative approach towards motivating climate change mitigation and finding realistic adaptation plans for West Africa.

Acknowledgements The authors would like to extend their gratitude to the journal editor and reviewers of this study, whose inputs have greatly improved the work presented.

Funding Fitzpatrick, Parker, Marsham, and Rowell were supported by the Natural Environment Research Council/Department for International Development (NERC/DFID) program AMMA-2050: African Monsoon Multidisciplinary Analysis for 2050 project — grant number NE/M017176/1. Finney, Marsham, and Rowell were funded by the NERC/DFID funded Integrating Hydro-Climate Science into Policy Decisions for ClimateResilient Infrastructure and Livelihoods in East Africa (HyCRISTAL, NE/M02038X/1). Jackson, Tucker and Stratton were supported by NERC/DFID via the FCFA funded project, Improving Model Processes for African Climate (IMPALA, NE/MO17176/1 and NE/M017214/1). Deva was supported by a NERC Industrial Case Award in collaboration with the Met Office (NE/M009793/1). Parker and Marsham were also supported by UK Research and Innovation as part of the Global Challengers Research Fund, African SWIFT programme, grant number NE/P021077/1. Parker was also supported by a Royal Society Wolfson Research Merit Award (20142018). Marsham was also supported by the National Centre for Atmospheric Science via the NERC/GCRF programme ACREW: Atmospheric hazard in developing Countries: Risk assessment and Early Warning.

Open Access This article is licensed under a Creative Commons Attribution 4.0 International License, which permits use, sharing, adaptation, distribution and reproduction in any medium or format, as long as you give appropriate credit to the original author(s) and the source, provide a link to the Creative Commons licence, and indicate if changes were made. The images or other third party material in this article are included in the article's Creative Commons licence, unless indicated otherwise in a credit line to the material. If material is not included in the article's Creative Commons licence and your intended use is not permitted by statutory regulation or exceeds the permitted use, you will need to obtain permission directly from the copyright holder. To view a copy of this licence, visit http://creativecommons.org/licenses/by/4.0/.

\section{References}

Abdalla EB, Kotby EA, Johnson HD (1993) Physiological responses to heat-induced hyperthermia of pregnant and lactating ewes. Small Rumin Res 11(2):125-134

Abel SJ, Boutle IA, Waite K, Fox S, Brown PRA, Cotton R, Lloyd G, Choularton TW, Bower KN (2017) The role of precipitation in controlling the transition from stratocumulus to cumulus cloud in a northern hemisphere cold-air outbreak. J Atmos Sci 74:2293-2314

Aggarwal, A., and R. Upadhyay (2013), Thermoregulation, in Heat stress and animal productivity, edited, pp. 125, Springer, India

Arakawa A, Schubert WH (1974) Interaction of a cumulus cloud ensemble with the large-scale environment, part 1. J Atmos Sci 31(3):674-701

Aranami K, Davies T, Wood N (2015) A mass restoration scheme for limited-area models with semi-Lagrangian advection. Q J R Meteorol Soc 141:1795-1803

Azongo DK, Awine T, Wak G, Binka FN, Oduro AR (2012) A time series analysis of weather variability and allcause mortality in the Kasena-Nankana districts of northern Ghana 1995-2010. Glob Health Action 5: 23195508

Bamba A, et al. (2017), AMMA-2050 technical report no. 4.0: atlas of climate change metrics V1 Rep

Barnabás B, Jäger K, Fehér A (2008) The effect of drought and heat stress on reproductive processes in cereals. Plant Cell Environ 31(1):11-38

Barry AA et al (2018) West Africa climate extremes and climate change indices. Int J Climatol 38(S1):e921-e938

Bastin J-F et al (2019) Ungerstanding climate change from a global analysis of city analogues. PLoS One 14(10): e0224120

Berry HL, Bowen K, Kjellstrom T (2010) Climate change and mental health: a causal pathways framework. Int J Public Health 55:123-132

Berthou S, Rowell DP, Kendon E, Stratton RA, Crook J, Wilcox C (2019) Improved climatological precipitation characteristics over West Africa at convection-permitting scale. Clim Dyn 53(3-4):1991-2011

Biasutti M (2013) Forced Sahel rainfall trends in the CMIP5 archive. J Geophys Res 118:1613-1623 
Birch CE, Marsham JH, Parker DJ, Taylor CM (2014a) The scale dependence and structure of convergence fields preceding the initiation of deep convection. Geophys Res Lett 41(13):4769-4776

Birch CE, Parker DJ, Marsham JH, Garcia-Carreras L, Copsey D (2014b) A seemless assessment of the role of convection in the water cycle of the west African monsoon. J Geophys Res Atmos 119(6):2890-2912

Bourque F, Willox AC (2014) Climate change: the next challenge for public mental health? Int Rev Psychiatry 26(4):415-422

Boutle IA, Eyre JEJ, Lock AP (2014) Seemless stratocumulus simulation across the turbulent gray zone. Mon Weather Rev 142:1655-1668

Casse C, Gosset M, Vischel T, Quantin G, Tanimoun BA (2016) Model-based study of the role of rainfall and land use-land cover in the changes in the occurrence and intensity of Niger red floods in Niamey between 1953 and 2012. Hydrol Earth Syst Sci 20:2841-2859

Ceccherini G, Russo S, Ameztoy I, Marchese AF, Carmona-Moreno C (2017) Heat waves in Africa 1981-2015, observations and reanalysis. Nat Hazards Earth Syst Sci 17:115-125

Challinor AJ, Watson J, Lobell DB, Howden SM, Smith DR, Chhetri N (2014) A meta-analysis of crop yield under climate change and adaptation. Nature Clim, Change

Challinor AJ, Parkes B, Ramirez-Villegas J (2015) Crop yield response to climate change varies with cropping intensity. Glob Chang Biol 21:1679-1688

Challinor AJ, Koehler A-K, Ramirez-Villegas J, Whitfield S, Das B (2016) Current warming will reduce yields unless maize breeding and seed systems adapt immediately. Nat Clim Chang 6:954-958

Charoensook R, Gatphayak K, Sharifi AR, Chaisongkram C, Brenig B, Knorr C (2012) Polymorphisms in the bovine HSP90AB1 gene are associated with heat tolerance in Thai indigenous cattle. Trop Anim Health Prod 44:921-928

Cianconi P, Betrò S, and Janiri L (2020), The impact of climate change on mental health: a systematic descriptive review. Front Psychiatry, 11(74)

Cooke RF, Daigle CL, Moriel P, Smith SB, Tedeschi LO, Vendramini JMB (2020) Cattle adapted to tropical and subtropical environments: social, nutritional, and carcass quality considerations. J Anim Sci 98(2):skaa014

Crook J, Klein C, Folwell SS, Taylor CM, Parker DJ, Stratton RA, Stein THM (2019) Assessment of the representation of West African storm lifecycles in convection-permitting simulations. Earth Space Sci 6(5): 818-835

Cunsolo A, Ellis NR (2018) Ecological grief as a mental health response to climate change-related loss. Nat Clim Chang 8:275-281

Dai A, Trenberth KE, Qian T (2004) A global dataset of palmer drought severity index for 1870-2002: relationship with soil moisture and effects of surface warming. J Hydrometeorol 5(6):1117-1130

DeSalvo KB, Hyre AD, Ompad DC, Menke A, Tynes LL, Muntner P (2007) Symptoms of posttraumatic stress disorder in a New Orleans workforce following Hurricane Katrina. J Urban Health 84(2):142-152

Di Baldassarre G, Montanari A, Lins H, Koutsoyiannis D, Brandimarte L, and Blöschl G (2010), Flood fatalities in Africa: from diagnosis to mitigation, Hydrol Land Surface Studies, 37(22)

Diallo I, Sylla MB, Giorgi F, Gaye AT, Camara M (2012) Multimodel GCM-RCM ensemble-based projections of temperature and precipitation over West Africa for the early 21st century. Int J Geophysics 2012:972896

Diallo I, Giorgi F, Deme A, Tall M, Mariotti L, Gaye AT (2016) Projected changes of summer monsoon extremes and hydroclimatic regimes over West Africa for the twenty-first century. Clim Dyn

Doherty TJ, Clayton S (2011) The psychological impacts of global climate change. Am Psychol 66(4):265-276

Dosio A (2017) Projection of temperature and heat waves for Africa with an ensemble of CORDEX regional climate models. Clim Dyn 49:493-519

Driedonks N, Rieu I, Vriezen WH (2016) Breeding for plant heat tolerance at vegetative and reproductive stages. Plant Reprod 29(1-2):67-79

Dunning CM, Black E, Allan RP (2018) Later wet seasons with more intense rainfall over Africa under future climate change. J Clim 31:9719-9738

Eberhardt BG, Satrapa RA, Capinzaiki CRL, Trinca LA, Barros CM (2009) Influence of the breed of bull (Bos taurus indicus vs. Bos taurus taurus) and the breed of cow (Bos taurus indicus, Bos taurus taurus and crossbred) on the resistance of bovine embryos to heat. Anim Reprod Sci 114(1-3):54-61

Egondi T, Kyobutungi C, Kovats S, Muindi K, Ettarh R, Rocklov J (2012) Time-series analysis of weather and mortality patterns in Nairobi's informal settlements. Glob Health Action 5:23195509

Evan AT, Flamant C, Lavaysse C, Kocha C, Saci A (2015) Water vapor-forced greenhouse Wwrming over the Sahara Desert and the recent recovery from the Sahelian drought. J Clim 28:108-123

Famien AM, Janicot S, Ochou AD, Vrac M, Defrance D, Sultan B, Noel T (2018) A bias-corrected CMIP5 dataset for Africa using the CDF-t method - a contribution to agricultural impact studies. Earth Syst Dynam 9:313-338

Fitzpatrick R GJ (2016), Analysis and prediction of the west African monsoon onset. Publication thesis, University of Leeds 
Fitzpatrick MC, Dunn RR (2019) Contemporary climatic analogs for 540 North American urban areas in the late 21 st century. Nat Commun 10:614

Fitzpatrick RGJ, Parker DJ, Marsham JH, Knippertz P, Bain CL (2015) The West African monsoon onset - a concise comparison of definitions. J Clim 28:8673-8694

Fitzpatrick RGJ, Parker DJ, Marsham JH, Knippertz P, Bain CL (2016) On what scale can we predict the agronomic onset of the West African monsoon? Mon Weather Rev 144:1571-1589

Fitzpatrick RGJ et al (2020) What drives intensification of mesoscale convective systems over the West African Sahel under climate change? J Clim 33:3151-3172

Fontaine B, Roucou P, Monerie P-A (2011) Changes in the African monsoon region at medium-term time horizon using 12 AR4 coupled models under the A1b emissions scenario. Atmos Sci Lett 12:83-88

Fontaine B, Janicot S, Monerie P-A (2013) Recent changes in air temperature, heat waves occurrences, and almospheric circulation in Northern Africa. J Geophys Res Atmos 118:8536-8552

Garcia-Carreras L, Marsham JH, Parker DJ, Bain CL, Milton SF, Saci A, Saleh-Ferroudj M, Ouchene B, Washington R (2013) The impact of convective cold pool outflows on model biases in the Sahara. Geophys Res Lett 40:1647-1652

Garcia-Carreras L, Challinor AJ, Parkes BJ, Birch CE, Nicklin KJ, Parker DJ (2015) The impact of parameterized convection on the simulation of crop processes. J Appl Meteorol Climatol 54:1283-1297

Ginexi EM, Welhs K, Simmens SJ, Hoyt DR (2000) Natural disaster and depression: a prospective investigation of reactions to the 1993 Midwest floods. Am J Community Psychol 28(4):495-518

Giraldo Osorio JD, Garcia Galiano SG (2012) Non-stationary analysis of dry spells in monsoon season of Senegal River basin using data from regional climate models (RCMs). J Hydrol 450-451:82-92

Guan K, Sultan B, Biasutti M, Baron C, Lobell DB (2017) Assessing climate adaptation options and uncertainties for cereal systems in West Africa. Agricul and Forest Meteorol 232:291-305

Hansen PJ (2004) Physiological and cellular adaptations of zebu cattle to thermal stress. Anim Reprod Sci 82-83: 349-360

Havenith G, van Middendorp H (1990) The relative influence of physical fitness, acclimatization state, anthropometric measures and gender on individual reactions to heat stress. Eur J Appl Physiol 61:419-427

Hayes K, Blashki G, Wiseman J, Burke S, Reifels L (2018) Climate change and mental health: risk, impacts and priority actions. Int J Ment Heal Syst 12:28

Jagadish SVK, Murty MVR, Quick WP (2015) Rice responses to rising temperatures - challenges, perspectives, and future directions. Plant Cell Environ 38(9):1686-1698

James R, Washington R, Rowell DP (2014) African climate change uncertainty in Peturbed physics ensembles: implications of global warming to 4C and beyond. J Clim 27:4677-4692

Kendon EJ, Stratton RA, Tucker S, Marsham JH, Berthou S, Rowell DP, Senior CA (2019) Enhanced future changes in wet and dry extremes over Africa at convection-permitting scale. Nat Commun 10:1794

Klutse NAB et al (2018) Potential impact of $1.5^{\circ} \mathrm{C}$ and $2^{\circ} \mathrm{C}$ global warming on consecutive dry and wet days over West Africa. Environ Res Lett 13:055013

Lafore J-P, Flamant C, Guichard F, Parker DJ, Bouniol D, Fink AH, Giraud V, Gosset M, Hall N, Holler H, Jones C, Protat A, Roca R, Roux F, Said F, Thorncroft C (2011) Progress in understanding of weather systems in West Africa. Atmos Sci Lett 12:7-12

Lavaysse C, Flamant C, Janicot S, Parker DJ, Lafore J-P, Sultan B, Pelon P (2009) Seasonal evolution of the West African heat low: a climatological perspective. Clim Dyn 33:313-330

Lavaysse C, Flamant C, Evan A, Janicot S, and Gaetani M (2015), Recent climatological trend of the Saharan heat low and its impact on the West African climate, Clim Dyn

Lélé IM, Lamb PJ (2010) Variability of the Intertropical Front (ITF) and rainfall over the West African SudanSahel Zone. J Clim 23:3984-4004

Luo Q (2011) Temperature thresholds and crop production: a review. Clim Chang 109:583-598

Ly M, Traore SB, Alhassane A, Sarr B (2013) Evolution of some observed climate extremes in the West African Sahel. Weather Climate Extremes 1:19-25

Mall R, Singh R, Gupta A, Srinivasan G, Rathore L (2006) Impact of climate change in Indian agriculture: a review. Clim Chang 78:445-478

Manning C, and Clayton S (2018), Threats to mental health and wellbeing associated with climate change. In Psycology and climate change: human perceptions, impacts, and responses, edited, pp. 217-244, Academic Press

Mariotti L, Coppola E, Sylla MB, Giorgi F, and Piani C (2011), Regional climate model simulation of projected 21 st century climate change over an all-Africa domain: comparison analysis of nested and driving model results., J Geophys Res 116(D15)

Marshall N, Adger WN, Benham C, Brown K, Curnock MI, Gurney GG, Marshall P, Pert PL, Thiault L (2019) Reef grief: investigation the relationship between place meanings and place change on the great barrier reef, Australia. Sustain Sci 14:579-597 
Marsham JH, Dixon N, Garcia-Carreras L, Lister GMS, Parker DJ, Knippertz P, Birch CE (2013) The role of moist convection in the West African monsoon system - insights from continental scale convectionpermitting simulations. Geophys Res Lett 40:1843-1849

Marteau R, Moron V, Philippon N (2009) Spatial coherence of monsoon onset over Western and Central Sahel (1950-2000). J Clim 22:1313-1324

Marteau R, Sultan B, Moron V, Alhassane A, Baron C, Traore SB (2011) The onset of the rainy season and farmers' sowing strategy for pearl millet cultivation in Southwest Niger. Agric For Meteorol 151:1356-1369

Meade RD, Akerman AP, Notley SR, McGinn R, Poirier P, Gosselin P, Kenny GP (2020) Physiological factors charaterizing heat-vulnerable older adults: a narrative review. Environ Int 144:105909

Mertz O, Mbow C, Reenberg A, Diouf A (2009) Farmers' perceptions of climate change and agricultural adaptation strategies in rural Sahel. Environ Manag 43(5):804-816

Michelangeli P-A, Vrac M, Loukos H (2009) Probabilistic downscaling approaches: application to wind cumulative distribution functions. Geophys Res Lett 36(11):L11708

Miescher E, Fortney SM (1989) Responses to dehydration and rehydration during heat exposure in young and older men. Am J Physiol: Regulatory, Integrative and Comparative Physiology 257(5):R1050-R1056

Mora C et al (2013) The projected timing of climate departure from recent variability. Nature 502(7470):183-187

Mora C et al (2017) Global risk of deadly heat. Nat Clim Chang 7:501-506

Moran DS, Shapiro Y, Laor A, Izraeli S, and Pandolf KB (1999), Can gender differences during exercise-heat stress be assessed by the physiological strain index?, Am J Physiol 276(6)

Moron V, Oueslati B, Pohl B, Rome S, Janicot S (2016) Trends of mean temperatures and warm extremes in northern tropical Africa (1961-2014) from observed and PPCA-reconstructed time series. J Geophys Res Atmos 121:5298-5319

Murphy AH (1993) What is a good forecast? An essay on the nature of goodness in weather forecasting. Weather Forecasing 8:281-293

Nangombe SS, Zhou T, Zhang W, Zou L, Li D (2019) High-temperature extreme events over Africa under 1.5 and $2^{\circ} \mathrm{C}$ of global warming. J Geophys Res Atmos 124:4413-4428

New M et al (2006) Evidence of trends in daily climate extremes over southern and West Africa. J Geophys Res Atmos 111:D14102

Niang I, Ruppel OC, Abdrabo MA, Essel A, Lennard C, Padgham J, Urquhart P (2014) Africa. In: Barros VR et al (eds) Climate change 2014: impacts, adaptation, and vulnerability. Part B: regional aspect, contribution of working group II to the fifth assessment report of the intergovernmental panel on climate change. Cambridge University Press, Cambridge, pp 1199-1265

Nicolosi E, Corbett JB (2018) Engagement with climate change and the environment: a review of the role of relationships to place. Local Environ 23(1):77-99

Nikulin G et al (2018) The effects of 1.5 and 2 degrees of global warming on Africa in the CORDEX ensemble. Environ Res Lett 13:065003

Nka BN, Oudin L, Karambiri H, Paturel JE, Ribstein P (2015) Trends in floods in West Africa: analysis based on 11 catchments in the region. Hydrol Earth Syst Sci 19:4707-4719

Norris FH, Friedman M, Watson P, Byrne C, Diaz E, Kaniasty K (2002) 60,000 disaster victims speak: part 1. An empirical review of the empirical literature. 1981-2001. Psychiatry 65:207-239

Norris FH, Murphy AD, Baker CK, Perilla JL (2004) Postdisaster PTSD over four waves of a panel study of Mexico's 1999 flood. J Trauma Stress 17(4):283-292

North CS (2014) Current research and recent breakthroughs on the mental health effects of disasters. Curr Psychiatry Rep 16(10):481

North CS, Pfefferbaum B (2013) Mental health response to community disasters: a systematic review. J Amer Med Assoc 310(5):507-518

Padhy SK, Sarkar S, Panigrahi M, Paul S (2015) Mental health effects of climate change. Indian J Occup Environ Med 19(1):3-7

Panthou G, Vischel T, Lebel T (2014) Recent trends in the regime of extreme rainfall in the Central Sahel. Int J Climatol 34:3998-4006

Panthou G, Lebel T, Vischel T, Quantin G, Sane Y, Ba A, Ndiaye M, Diongue-Niang A, Diop Kane M (2018) Rainfall intensification in tropical semi-arid regions: the Sahelian case. Environ Res Lett 13(6):064013

Parkes B, Sultan B, Ciais P (2018) The impact of future climate change and potential adaptation methods on maize yields in West Africa. Clim Chang 151(2):205-217

Patricola CM, Cook KH (2010) Northern African climate at the end of the 21st century: integrated application of regional and global climate models. Clim Dyn 35(1):193-212

Patz J, Campbell-Lendrum D, Gibbs H, Woodruff R (2008) Heath impact assessment of global climate change: expanding on comparative risk assessment approaches for policy making. Annu Rev Public Health 29:27-39

Pennelly C, Reuter G, Flesch T (2014) Verification of the WRF model for simulating heavy precipitation in Alberta. Atmos Res 135-136:172-192 
Porch, T. G., and A. E. Hall (2013), Heat tolerance, in Genomics and breeding for climate-resilient crops, edited, pp. 167-202, Springer, Berlin

Porter JR, Gawith M (1999) Temperatures and the growth and development of wheat: a review. Eur J Agron 10(1):23-36

Prasad PVV, Bheemanahalli R, Krishna Jagadish SV (2017) Field crops and the fear of heat stress - opportunities, challenges and future directions. Field Crop Res 200:114-121

Reiser L (2017), Extreme heat takes a toll on our mental health, edited by J. Constible, Natural Resource Defense Council

Reynolds RW, Smith TM, Liu C, Chelton DB, Casey KS, Schlax MG (2007) Daily high-resolution-blended analyses for sea surface temperature. J Clim 20:5473-5496

Riede JO, Posada R, Fink AH, Kasper F (2016) What's on the 5th IPCC report for West Africa? In: Yaro JA, Hesselberg $\mathrm{J}$ (eds) Adaption to climate change and variability in rural West Africa. Springer Int. Pub, Switzerland

Rodriguez-Fonseca B, et al. (2015), Climate variability and predictability of West African droughts

Russo S, Dosio A, Graversen RG, Sillmann J, Carrao H, Dunbar MB, Singleton A, Montagna P, Barbola P, Vogt JV (2014) Magnitude of extreme heat waves in present climate and their projection in a warming world. J Geophys Res Atmos 119(22):12,500-12,512

Sánchez B, Rasmussen A, Porter JR (2014) Temperatures and the growth and development of maize and rice: a review. Glob Chang Biol 20:408-417

Seif SM, Johnson HD, Lippincott AC (1979) The effects of heat exposure $\left(31^{\circ} \mathrm{C}\right)$ on Zebu and Scottish Highland cattle. Int J Biometeorol 23:9-14

Serdeczny O, Adams S, Baarsch F, Coumou D, Robinson A, Hare W, Schaeffer M, Perrette M, Reinhardt J (2017) Climate change impacts in sub-Saharan Africa: from physical changes to their social repercussions. Reg Environ Chang 17:1585-1600

Smith RNB (1990) A scheme for predicting layer clouds and their water content in a general circulation model. Q J R Meteorol Soc 116:435-460

Smith KR et al (2014) Human health: impacts, adaptation, and co-benefits. In: Field CB, Barros VR, Dokken DJ, Mach KJ, Mastrandrea MD, Bilir TE (eds) Climate change 2014: impacts, adaptation, and vulnerability. Part A: global and sectoral aspects. Contribution of Working Group II to the Fifth Assessment Report of the Intergovernmental Panel on Climate Change. Cambridge University Press, New York, pp 709-755

Stratton RA et al (2018) A pan-African convection-permitting regional climate simulation with the met Office unified model: CP4-Africa. J Clim 31:3485-3508

Sultan B, and Gaetana M (2016), Agriculture in West Africa in the twenty-first century: climate change and impacts scenarios and potential for adaptation, Front Plant Sci, 7

Sultan B, Janicot S (2000) Abrupt shift of the ITCZ over West Africa and intra-seasonal variability. Geophys Res Lett 27(20):3353-3356

Sultan B, Janicot S (2003) The West African monsoon dynamics. Part II: the "preonset" and "onset" of the summer monsoon. J Clim 16:3407-3427

Sultan B, Roudier P, Quirion P, Alhassane A, Muller B, Dingkuhn M, Ciais P, Guimberteau M, Traore S, Baron C (2013) Assessing climate change impacts on sorghum and millet yields in the Sudanian and Shaelian savannas of West Africa. Environ Res Lett 8(1):014040

Sylla MB, Pal JS, Faye A, Dimobe K, Kunstmann H (2018) Climate change to severely impact West African basic scale irrigation in $2^{\circ} \mathrm{C}$ and $1.5^{\circ} \mathrm{C}$ global warming scenarios. Sci Rep 8:14395

Tarhule A (2005) Damaging rainfall and flooding: the other Sahel hazards. Clim Chang 72:355-377

Taylor CM, Belušić D, Guichard F, Parker DJ, Vischel T, Bock O, Harris PP, Janicot S, Klein C, Panthou G (2017) Frequency of extreme Sahelian storms tripled since 1982 in satellite observations. Nature 544:475-478

Tazan F, Diarra A, Kabore RFW, Ibrahim B, Bologo Traore M, Traore K, and Karambiri H (2018), Trends in flood events and their relationship to extreme rainfall in an urban area of Sahelian West Africa: the case study of Ouagadougou, Burkina Faso. J Flood Risk Manag. https://doi.org/10.1111/jfr3.12507

Thorncroft CD, Nguyen H, Zhang C, and Peyrille P (2011), Annual cycle of the West African monsoon: regional circulations and associated water vapour transport, Q J R Meteorol Soc, 137

Trombley J, Chalupka S, Anderko L (2017) Climate change and mental health. Am J Nurs 117(4):44-52

Vins H, Bell J, Saha S, Hess JJ (2015) The mental health outcomes of drought: a systematic review and causal process diagram. Int J Environ Res Public Health 12(10):13251-13275

Visman E, et al. (2017), Learning paper \#6: developing decision-relevant climate information and supporting its appropriate application. Rep, King's College London and Christian aid

Viswanath B, Maroky AS, Math SB, John JP, Cherian AV, Girimaji SC, Benegal V, Hamza A, Chaturvedi SK (2013) Gender differences in the psychological impact of tsunami. Int J Soc Psychiatry 59(2):130-136 
Vizy EK, Cook KH (2012) Mid-twenty-first-century changes in extreme events over northern and tropical Africa. J Clim 25:5748-5767

Vizy EK, Cook KH (2018a) Mesoscale convective systems and nocturnal rainfall over the West African Sahel: role of the inter-tropical front. Clim Dyn 50:587-614

Vizy EK, and Cook KH (2018b), Understanding the summertime diurnal cycle of precipitation over sub-Saharan West Africa: regions with daytime rainfall peaks in the absence of significant topographical features, Clim Dyn

Vizy EK, Cook KH, Cretat J, Neupane N (2013) Projections of a wetter Sahel in the twenty-first century from global and regional models. J Clim 26:4664-4687

Vrac M, Noël T, Vautard R (2016) Bias correction of precipitation through singularity stochastic removal: because occurrences matter. J Geophys Res Atmos 121:5237-5258

Weber T, Haensler A, Rechid D, Pfeifer S, Eggert B, Jacob D (2018) Analyzing region climate change in Africa in a $1.5,2$, and $3^{\circ} \mathrm{C}$ global warming world. Earth's Future 6:643-655

Weedon GP, Balsamo G, Bellouin N, Gomes S, Best MJ, Viterbo P (2014) The WFDEI meteorological forcing data set: WATCH forcing data methodology applied to ERA-interim reanalysis data. Water Resour Res 50: 7505-7514

Wilby R, Dessai S (2010) Robust adaptation to climate change. Weather 65(7):180-185

Wilcox C, Vischel T, Panthou G, Bodian A, Blanchet J, Descroix L, Quantin G, Casse C, Tanimoun BA, Kone S (2018) Trends in hydrological extremes in the Senegal and Niger Rivers. J Hydrol 566:531-545

Willox AC, Harper SL, Ford JD, Edge VL, Landman K, Houle K, Blake S, Wolfrey C (2013) Climate change and mental health: an exploratory case study from Rigolet, Nunatsiavut, Canada. Clim Change 121:255-270

Wilson D (2017), Ability of physiological strain index to discriminate between sustainable and unsustainable heat stress, $43 \mathrm{pp}$, University of South Florida

Yapo ALM, Diawara A, Yoroba F, Kouassi BK, Sylla MB, Kouadio K, Odoulami RC, Tiémoko DT (2019) Twenty-first century projected changes in extreme temperature over Côte d'Ivoire (West Africa). Int J Geophysics 2019:5610328

Zenko M, Menga F (2019) Linking water scarcity to mental health: hydro-social interruptions in the Lake Urmia Basin, Iran. Water 11(5):1092

Publisher's note Springer Nature remains neutral with regard to jurisdictional claims in published maps and institutional affiliations. 